\title{
The Subprimary Range of Firing Is Present in Both Cat and Mouse Spinal Motoneurons and Its Relationship to Force Development Is Similar for the Two Species
}

\author{
D.Dennis Bo Jensen, ${ }^{1}$ - Katinka Stecina, ${ }^{1}$ - Jacob Wienecke, ${ }^{1,2}{ }^{\circledR}$ Anne Hedegaard, ${ }^{1}$ Natalya Sukiasyan, ${ }^{1}$ \\ Hans R. Hultborn, ${ }^{1}$ and ${ }^{-C}$ Claire Francesca Meehan ${ }^{1}$ \\ ${ }^{1}$ Department of Neuroscience and ${ }^{2}$ Department of Nutrition, Exercise, and Sports, University of Copenhagen, Panum Institute, Copenhagen, Denmark 2200
}

In the motor system, force gradation is achieved by recruitment of motoneurons and rate modulation of their firing frequency. Classical experiments investigating the relationship between injected current to the soma during intracellular recording and the firing frequency (the $I-f$ relation) in cat spinal motoneurons identified two clear ranges: a primary range and a secondary range. Recent work in mice, however, has identified an additional range proposed to be exclusive to rodents, the subprimary range (SPR), due to the presence of mixed mode oscillations of the membrane potential. Surprisingly, fully summated tetanic contractions occurred in mice during SPR frequencies. With the mouse now one of the most popular models to investigate motor control, it is crucial that such discrepancies between observations in mice and basic principles that have been widely accepted in larger animals are resolved. To do this, we have reinvestigated the $I-f$ relation using ramp current injections in spinal motoneurons in both barbiturate-anesthetized and decerebrate (nonanesthetized) cats and mice. We demonstrate the presence of the SPR and mixed mode oscillations in both species and show that the SPR is enhanced by barbiturate anesthetics. Our measurements of the $I-f$ relation in both cats and mice support the classical opinion that firing frequencies in the higher end of the primary range are necessary to obtain a full summation. By systematically varying the leg oil pool temperature (from $37^{\circ} \mathrm{C}$ to room temperature), we found that only at lower temperatures can maximal summation occur at SPR frequencies due to prolongation of individual muscle twitches.

Key words: cat; motoneuron; mouse; subprimary range

Significance Statement

This work investigates recent revelations that mouse motoneurons behave in a fundamentally different way from motoneurons of larger animals with respect to the importance of rate modulation of motoneuron firing for force gradation. The current study systematically addresses the proposed discrepancies between mice and larger species (cats) and demonstrates that mouse motoneurons, in fact, use rate modulation as a mechanism of force modulation in a similar manner to the classical descriptions in larger animals.

\section{Introduction}

In the motor system force gradation is achieved by two mechanisms, the sequential recruitment of motor units according to the size principle (Henneman, 1957) and rate modulation of the firing frequency of recruited motor units. Increases in the firing frequency of the motoneuron results in summation of the forces of individual muscle twitches which, at high enough firing frequencies, results in fused tetanic contractions.
The way that the motoneuron converts its synaptic inputs into outputs of specific frequencies has been explored extensively in cat motoneurons. Here, current injection to the soma is frequently used to mimic synaptic input. The current intensity is then varied (using either square pulses or triangular current ramps) and the resultant firing frequency of the motoneuron measured. The slopes of these input-output relationships ( $I-f$ slopes) have historically been characterized in cat as displaying

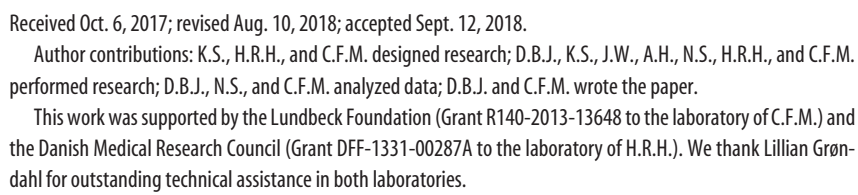

The authors declare no competing financial interests.

Correspondence should be addressed to Claire Francesca Meehan, Department of Neuroscience, University of Copenhagen, Panum Institute, Blegdamsvej 3, 2200 Copenhagen N, Denmark. E-mail: claire@sund.ku.dk. https://doi.org/10.1523/JNEUROSCI.2898-17.2018

Copyright $\odot 2018$ the authors $\quad 0270-6474 / 18 / 389741-13 \$ 15.00 / 0$ 
two distinct linear ranges: the primary range and the secondary range (Granit et al., 1966a,b).

The minimum firing frequency of the motoneuron is related to the duration of the postspike afterhyperpolarization (AHP) (Kernell, 1965), which in turn is correlated to the twitch duration of the motor unit's muscle fibers (Zengel et al., 1985; Gardiner and Kernell, 1990; Bakels and Kernell, 1993), an observation consistent across species (for review, see Meehan et al., 2010). The close relationship between the AHP duration and muscle twitch ensures a rapid summation of muscle twitches with increases in firing frequency. The firing frequency increases linearly with input during the primary range (Granit et al., 1966a) until a certain point at which the slope suddenly steepens, referred to as the secondary range (Granit et al., 1966b), when the injected current is large enough to activate dendritic ion channels mediating persistent inward currents (Schwindt and Crill, 1982; Hounsgaard and Kiehn, 1989; Bui et al., 2006).

Although much of this information has been derived from cats, transgenic models of motor disorders has made the mouse a popular model to investigate spinal motor control. It is therefore crucial to establish the same relationship among input, output, and gradation of force in mice. Initial studies of mouse motoneurons, however, have suggested fundamental differences (Manuel et al., 2009; Manuel and Heckman, 2011).

During slow triangular current ramp injections in motoneurons in barbiturate-anesthetized mice, high-frequency oscillations were observed immediately subspike threshold, which continued during the initial first spike intervals and were therefore referred to as mixed mode oscillations (MMOs) (Manuel et al., 2009). These created an extra range in the $I-f$ slope referred to as the subprimary range (SPR) in addition to the previously described ranges. It was suggested that the SPR is unique to mice (Manuel et al., 2009). Furthermore, by recording ramp current injections in motoneurons simultaneous with force recordings, a surprising result was observed. Almost maximal tetanic force could be achieved during the SPR in mice (Manuel and Heckman, 2011).

Since these initial observations in mice, the SPR has also been described in rat motoneurons (Turkin et al., 2010), suggesting that they are not necessarily unique to mice. MMOs are thought to arise due to a low excitability state (Iglesias et al., 2011), which could result from the barbiturate anesthetic used. Much of the work on the $I-f$ slopes in cats originates from nonanesthetized decerebrate preparations and this could explain the discrepancy. We therefore investigated $I-f$ slopes obtained from motoneurons in both decerebrate and barbiturate-anesthetized cats and mice using similar triangular current injection. This revealed that the MMOs and the SPR are also present in cat motoneurons; however, little summation of muscle twitches occurred during these firing frequencies. Surprisingly, we were unable to achieve maximal tetanic force in mice using stimulation of sciatic nerves at frequencies corresponding to the transition from the SPR to the primary range, when the muscle oil pool was maintained at $37^{\circ} \mathrm{C}$. This confirms that the principle of rate coding and its relationship to muscle force is fundamentally similar in both species.

\section{Materials and Methods}

\section{Procedures}

Surgical and experimental procedures were conducted in accordance with the EU Directive 2010/63/EU and with National Institutes of Health's Guidelines for the Care and Use of Laboratory Animals (National Institutes of Health publication no. 86-23, revised 1985). All procedures were approved by the Danish Animal Experimentation Inspectorate (permission numbers: 2010/561-1825, 2012-15-2934-00501 and 201515-0201-00545).

\section{Cats}

Data were obtained from 11 adult cats (7 male, 4 female, $2.7-5.1 \mathrm{~kg}$ purpose-bred for research). Six of these cats (five anesthetized with barbiturates and one decerebrate) were used specifically for this study. The remaining decerebrate cats were from a previously published set of experiments (Wienecke et al., 2009) from the same laboratory in which similar ramp current injection was used but with different objectives.

\section{Mice}

Overall, data were obtained from 25 adult C57BL76J mice ( 12 female, 13 male, 12-15 weeks old, $\sim 25 \mathrm{~g}$, from Charles River Laboratories and Janvier). $I-f$ slopes ( primary range) from eight of the mice (females) have been previously used to demonstrate the viability of motoneurons in decerebrate mouse preparations (Meehan et al., 2017).

\section{Anesthesia}

Barbiturate-anesthetized cats. Anesthesia of 5 cats was initially induced by isoflurane ( $5 \%$ isoflurane in $70 \% \mathrm{~N}_{2} \mathrm{O}$ and $30 \% \mathrm{O}_{2}$ ). Cats were subsequently anesthetized with an IV injection of $\mathrm{Na}^{+}$pentobarbital (Mebumal, $37 \mathrm{mg} / \mathrm{kg}$ ). Atropine $(0.1 \mathrm{mg} / \mathrm{kg}$, subcutaneous) was administered shortly after vital signs stabilized after the induction. The blood pressure was monitored continuously via a carotid artery catheter and cannulae were also placed in both forelimb brachial veins for administration of drugs. Anesthesia was maintained throughout the entire experiment with maintenance doses $(4 \mathrm{mg} / \mathrm{kg}$ ) when necessary, tested regularly by increases in blood pressure or reflexes in response to a noxious pinch to the hindpaw. Administration of Solumedrol (2.5 $\mathrm{mg} / \mathrm{kg}$, i.v.) and a glucose/bicarbonate buffer solution (10\% dextrose and $1.7 \% \mathrm{NaHCO}_{3}$ ) at a rate of 2.5 to $4.0 \mathrm{ml} / \mathrm{h}$ intravenously was routinely used for cats on the basis of changes in blood pressure throughout the experiment.

Decerebrate cats. In the decerebrate animals, the initial procedure was as described above except that anesthesia was maintained throughout the surgery with isoflurane $(0.8-1.5 \%)$ delivered in an oxygenated mixture of nitrous oxide $\left(50 \% \mathrm{~N}_{2} \mathrm{O}, 50 \% \mathrm{O}_{2}\right)$ until the decerebration. Anemic decerebration was achieved by ligation of the basilar artery and both common carotid arteries, removing the blood supply to the entire brain rostral to the pons (Crone et al., 1988). The isoflurane was then discontinued and decerebration was confirmed to be complete by the development of a tonic extensor tone, lack of spontaneous movement, and a lack of pupil reflexes. The neuromuscular blocker Pavulon (pancuronium bromide; $0.2 \mathrm{mg} / \mathrm{kg}$ for cats, supplemented every $40-60 \mathrm{~min}$ ) was then administered and animals ventilated to maintain end tidal $\mathrm{CO}_{2}$ at $4-6 \%$. For one cat, a mechanical decerebration was performed. For this, a craniotomy was performed and the animal was mechanically decerebrated at the precollicular postmammillary level and all brain tissue rostral to the transection was removed. As for the barbiturate cats, the blood pressure was monitored and mean arterial blood pressure was maintained $>80 \mathrm{mmHg}$, if necessary, by infusion of $10 \%$ dextrose and $1.7 \%$ $\mathrm{NaHCO}_{3}$.

Barbiturate-anesthetized mice. A brief anesthesia was induced with isoflurane. A longer-lasting anesthesia was then induced and maintained with intraperitoneal injections of $\mathrm{Na}^{+}$pentobarbital ( $1.5 \mathrm{mg} /$ mouse). Supplementary doses $(0.03 \mathrm{mg})$ were given as necessary (tested by reflexes in response to a noxious pinch to the hindpaw). All mice received a single dose of Atropine ( $0.02 \mathrm{mg}$, s.c.) at the start of the surgery to reduce mucous secretions. For intracellular experiments, the neuromuscular blocking agent Pavulon was then administered $(0.03 \mathrm{mg})$ and the mice ventilated with a mixture of oxygen and air ( $\sim 72$ breaths $/ \mathrm{min})$. Expired $\mathrm{CO}_{2}$ levels were measured using a Capstar $\mathrm{CO}_{2}$ analyzer (CWE). Under neuromuscular blockage, maintenance dosages of anesthesia were given at the same rates necessary for the surgical procedures. ECG was monitored using clips placed on the ear and rear foot to monitor effectiveness of anesthesia and additional maintenance doses of anesthesia were administrated in response to any increases in heart rate.

Decerebrate mice. This decerebration protocol in mice is described in more depth in Meehan et al. (2017), where we demonstrated not only the 
method but the viability of intracellular recording in such preparations. These mice were initially anesthetized with isoflurane $(\sim 2 \%)$ via a nose cone and given a single dose of Atropine $(0.02 \mathrm{mg})$ subcutaneously at the start of the surgery. Following the initial surgery, these mice were moved to the recording frame and artificially ventilated as above $(72 \mathrm{breath} / \mathrm{min}$, mixture of air and oxygen) via a tracheal cannula but with isoflurane added to the flow and expired $\mathrm{CO}_{2}$ levels monitored. A craniotomy was performed and the brain (rostral to the superior colliculus) was then removed. An absorbable hemostat (Surgicel, Ethicon) was immediately placed in the void along with small crystals of dry ice (avoiding the brainstem). Once bleeding had subsided, the Surgicel was removed and the completeness of the decerebration confirmed before removal of isoflurane. Ten minutes after removal of the anesthetic the neuromuscular blocking agent Pavulon was then administered as for the other mice and recording from motoneurons commenced $\sim 1 \mathrm{~h}$ after the removal of the anesthetic. Heart rate was also constantly monitored in decerebrate mice using clips placed in the ear and hindlimb. In addition, expired $\mathrm{pCO}_{2}$ was measured using a Capstar monitor throughout the experiment. This dropped suddenly with the decerebration and then within a few minutes returned to $>4 \%$ and then remained stable across the entire recording period, fluctuating only slightly (by $0.1-0.2$ ) in response to subtle fluctuations in temperature $\left(\sim 0.2^{\circ} \mathrm{C}\right)$.

\section{Preparation for electrophysiology experiments}

Cats. The following hindlimb nerves were dissected on the left side: the multifunctional hamstring muscles posterior biceps and semitendinosus (PBSt), the semimembranosus and anterior biceps (SmAB), the cutaneous sural (Sur), the medial and lateral gastrocnemious and soleus (GS), plantaris $(\mathrm{Pl})$, the tibialis anterior (TA) and extensor digitorum longus (EDL), often TA and EDL together as deep peroneal (DP), the cutaneous superficial peroneal (SP), the mixed cutaneous and muscle posterior tibial (Tib) and the flexor digitorum and hallucis longus (FDHL). In experiments in which muscle force was not measured, the peripheral nerves were cut distally and the proximal stump was freed from connective tissue. The hindlimb was fixed in a semi-extended position to allow for the construction of a paraffin pool using the skin covering the hindlimb and the dissected nerves were placed on bipolar silver hook electrodes. A laminectomy was performed over the L3-L6 vertebrae and the skin retracted to form a pool filled with paraffin oil.

In the barbiturate experiments, the gastrocnemius nerve was left intact, the gastrocnemius muscle was isolated, and the distal tendon was sectioned and tied with a silk thread attached to a force transducer (Series 300B lever system, Cambridge Technology). The oil in the leg pool completely covered the muscle. During all experiments, the temperature of the animal's core was maintained at physiological levels using a thermoregulated heating system. In force experiments, a separate temperature probe and heat lamp were used to additionally control the temperature of the leg oil pool.

Mice. Surgery and electrophysiological recordings were performed as described previously (Meehan et al., 2010). Following the induction of anesthesia, intraperitoneal cannulae were inserted for further drug delivery. A tracheal cannula was inserted, the sciatic nerve was dissected, and a laminectomy was performed at vertebral levels T13 and L1. The mice were then placed in a stereotactic frame with vertebral clamps on the T12 and $\mathrm{L} 2$ vertebrae. The temperature was monitored using a rectal probe and maintained at $37^{\circ} \mathrm{C}$ using a heat pad underneath and a heat lamp above the mouse controlled by the output from the temperature probe.

All mice and cats (whether paralyzed or not) for all types of experiments were artificially ventilated and the expired $\mathrm{CO}_{2}$ was monitored and maintained between $3.0 \%$ and $5.0 \%$ during artificial ventilation,

\section{Intracellular recording (cats and mice)}

Intracellular recordings were obtained using pulled-pipette glass microelectrodes filled with $2 \mathrm{M}$ potassium acetate (3-10 $\mathrm{M} \Omega$ for cats and $\sim 25$ $\mathrm{M} \Omega$ for mice) and amplified with an Axoclamp 2A microelectrode amplifier in all preparations. Hindlimb nerves were stimulated to allow antidromic identification of intracellularly impaled motoneurons. A ball electrode was placed on the dorsal surface of the spinal cord typically near the L6-L7 spinal segment in the cat and L3-L4 in the mouse to record the incoming afferent volley associated with peripheral nerve stimulation $(0.1 \mathrm{~ms}$ pulse, intensity based on $5 \times$ threshold required for activating the most excitable fibers).

Intracellular recordings were amplified and filtered using custom made filters (University of Copenhagen) and digitized using a CED 1401 digital to analog converter $(20-40 \mathrm{kHz}$ for intracellular recordings, 20 $\mathrm{kHz}$ for force measurements) and recorded using Spike 2 version 6 Software (Cambridge Electronic Design).

All motoneurons included in the study had membrane potentials more hyperpolarized than $-50 \mathrm{mV}$, with overshooting action potentials (in bridge mode) and exhibited repetitive firing in response to current injection to the soma. $I-f$ slopes measured in the primary range firing were not significantly different between motoneurons in decerebrate mice and anesthetized mice ( $p=0.5907$ Mann-Whitney), demonstrating that there was no deterioration in the quality of the motoneurons in the decerebrate preparations.

Triangular ramps of current ( $5 \mathrm{nA} / \mathrm{s}$ in mice and $5-10 \mathrm{nA} / \mathrm{s}$ in cat) were injected through the microelectrodes using discontinuous currentclamp (DCC) mode on the Axoclamp amplifier ( $3 \mathrm{kHz}$ for all cells initially and then additionally $8 \mathrm{kHz}$ or Bridge mode in some cells) to evoke repetitive firing of action potentials. The $I-f$ slope was determined by calculating the instantaneous firing frequency using the Spike2 software. In the cats anesthetized with barbiturates, during ramp current injections to the soma of gastrocnemius motoneurons, the resulting force of the whole muscle was then measured. The frequency of subthreshold oscillations was measured manually using the crossing of the membrane potential $\left(V_{\mathrm{m}}\right)$ of a straight line of best fit and then a mean cycle period was calculated to obtain the frequency.

To measure the postspike AHP, brief current pulses were injected though the microelectrode to initiate a single action potential. Measurements of the postspike AHP were made from averages of successive trials. The exact return of the AHP to baseline was not always easy to detect, so the time for the $V_{\mathrm{m}}$ to return by $2 / 3$ of the peak amplitude of the AHP (AHP 2/3) was used for statistical comparisons.

Mean values for resting $V_{\mathrm{m}}$ (before ramp current injections) for the cells included in these analyses were not significantly different between barbiturate-anesthetized and decerebrate animals (mouse: barbiturate: mean $=-67.18 \mathrm{mV}, \mathrm{SD}=7.77$, decerebrate: mean $=-66.81 \mathrm{mV}, \mathrm{SD}=$ 9.25; cat: barbiturate: mean $=64.6 \mathrm{mV}, \mathrm{SD}=9.59$, decerebrate: mean $=$ $-67.61 \mathrm{mV}, \mathrm{SD}=7.96)$.

\section{Muscle force experiments in mice}

In seven mice (anesthetized with $\mathrm{Na}^{+}$pentobarbital), the muscle twitch of the triceps surae muscles was recorded. In these mice, the sciatic nerve was dissected, ligated, and cut proximally. Distally, the peroneal branch and the branches of the tibial nerve innervating muscles other than medial and lateral gastrocnemius and soleus were cut to achieve a selective contraction of these muscles by sciatic nerve stimulation. The knee region (femur and tibia) and the ankle were fixed by pins and the Achilles tendon was attached to the force transducer. The muscle was gradually stretched to obtain the optimal length (largest twitch) and the stimulus intensity gradually increased to the point at which the amplitude of the twitch did not increase further. These settings were then used for the rest of the experiment. In these experiments in mice, the stimulator was triggered and force data recorded (after passing through a Humbug noise eliminator, Quest Scientific) using Signal software (Cambridge Electronic Design). The experimental protocol consisted first of single stimuli given at a frequency of $0.05 \mathrm{~Hz}$. After $\sim 5-10$ single twitches, trains of 10 stimuli were delivered at increasing frequencies from 10 to $120 \mathrm{~Hz}$ (in increments of $10 \mathrm{~Hz}$ ) with $60 \mathrm{~s}$ of rest between each stimulus train.

In these experiments, a separate temperature probe and heat lamp were used to control the temperature of the leg oil pool distinct from the core temperature. Before the protocol was started, the leg oil pool was stabilized at $37^{\circ} \mathrm{C}$ (recorded at different locations in the oil pool including down the lateral side of the muscle and between the triceps surae muscles and the underlying muscles). After the first round of the protocol was complete, the heating for the leg pool was turned off while the core body temperature was maintained at $37^{\circ} \mathrm{C}$. This resulted in a leg pool temperature of $\sim 30-32^{\circ} \mathrm{C}$. After the leg pool temperature had sta- 
bilized at $32^{\circ} \mathrm{C}$ (as described above), the protocol was repeated. After this second round, the temperature of the leg pool was further cooled down to $25^{\circ} \mathrm{C}$ by the addition of cold paraffin oil and the protocol run a third time. Finally, the heat lamp for the leg pool was turned on again and, when the leg oil pool temperature returned to $37^{\circ} \mathrm{C}$, the protocol was repeated a fourth and last time.

The single twitches were averaged and the amplitude, width at $1 / 2$ amplitude, and width at $1 / 2$ relaxation time were measured. The time to peak was also measured using an increase in the rate of rise of $\geq 0.034 \mathrm{mN} / \mathrm{ms}$ as the start time. For the stimulus trains, the peak amplitude of the force was measured at all frequencies and expressed as a percentage of the overall maximum force for that muscle.

\section{Experimental design and statistical analysis}

All statistical tests were performed using GraphPad Prism software. D'Agostino and Pearson omnibus normality tests were used to confirm that data were normally distributed. For data passing this test, parametric statistics were used. For data not passing the normality tests (or with a low number of observations), nonparametric statistics were used (specific tests are described for each analysis in Tables 1, 2, and 3). For AHP/ SPR analysis, linear regression was performed for each group and, if this was significant, then the data were tested for a significant difference between the slopes and the elevation (intercept) of the slopes. Statistical significance was accepted at the $p \leq 0.05$ level. On all graphs, asterisks are used to indicate the following significance levels: ${ }^{*} p \leq 0.05,{ }^{* *} p \leq 0.01$, ${ }^{* * *} p \leq 0.001$, and ${ }^{* * *} p \leq 0.0001$. Unless indicated on the graphs, no significant difference was found. More extensive details of each individual set of statistical analyses are provided in Tables 1, 2, and 3.

\section{Results}

\section{SPR is enhanced by barbiturate anesthesia}

Because modeling has previously suggested that the SPR in mice is the result of a low excitability state (Iglesias et al., 2011), we compared $I-f$ slopes in barbiturate-anesthetized mice $(n=48$ cells, 7 mice) with those recorded in decerebrate (nonanesthetized) mice ( $n=31$ cells, 7 mice). SPRs were observed in motoneurons of both anesthetized and decerebrate mice (Fig. 1A, left column). The firing frequency at which the transition from SPR to primary range occurred was significantly correlated with AHP duration (measured when it had returned by $2 / 3$ of its amplitude) for both groups (both $p<0.0001$, Fig. $1 B$, Table 1 ). The degree of slope was not significantly different between the groups $(p=0.8644)$, confirming that the transition point is equally dependent on AHP duration in both groups. The regression line for anesthetized mice, however, was significantly elevated (i.e., the transition occurs at higher firing frequencies $(p<0.0001)$, suggesting that the barbiturate anesthesia delays the onset of the primary range. To determine whether this effect could be attributed to barbiturate anesthesia, in a further four mice (19 cells), we administered $\mathrm{Na}^{+}$pentobarbital after decerebration and measured the frequency at transition from SPR to primary range and AHP. Neither the slope nor the elevation of the regression line for this group was significantly different from that measured for the barbiturate-only group ( $p=0.9404$ and $p=0.5558$, respectively).

The higher firing frequency at which the SPR-primary range transition occurs in anesthetized mice is due to an overall increase in the SPR in anesthetized animals because the total SPR (transition frequency - minimum firing frequency) was significantly lower in the decerebrate mice ( $p=0.0165$, Fig. $1 D$, Table 2$)$.

\section{SPR is present in both cat and mouse motoneurons}

$I-f$ slopes were obtained in response to triangular current injection in motoneurons in barbiturate-anesthetized ( $n=51$ cells, 5 cats) and decerebrate ( $n=54$ cells, 6 cats) cats. Both also showed SPRs (Fig. $1 A$, right column), demonstrating that the SPR is not a feature unique to mice. As was the case for mice, the firing fre- quency at which the transition from SPR to primary range was significantly correlated with AHP duration (measured when it had returned by $2 / 3$ of the amplitude) for both groups (both $p<$ 0.0001 , Fig. $1 C$ ). The barbiturate anesthetic had a similar effect in cats with a significantly higher firing frequency at the transition from SPR to primary range (higher slope elevation, $p<0.0002$ ), but no difference in the degree of the slope $(p=0.7578$, Fig. $1 C)$. Again, this higher SPR-primary range transition occurs in anesthetized cats due to a significant increase in the total SPR ( $p=$ 0.0055 , Fig. 1E, Table 2).

\section{Subthreshold oscillations are present in motoneurons in both} anesthetized and decerebrate mice and cats

As the motoneurons were depolarized by the current injection, just before action potential threshold, small oscillations occurred in motoneurons in both anesthetized and decerebrate mice (Fig. $2 A$ ). These were similar to what has been previously reported in anesthetized mice (Manuel et al., 2009) and had mean frequencies of $126.3 \mathrm{~Hz}( \pm 23.13 \mathrm{SD})$ in the barbiturate-anesthetized mice and $130.4 \mathrm{~Hz}( \pm 17.5 \mathrm{SD})$ in the decerebrate mice, which was not significantly different $(p=0.9558$, Fig. $2 B$, Table 3$)$. These oscillations were rarely observed when switching frequencies of $3 \mathrm{kHz}$ (DCC mode) were used. They became more obvious when using $8 \mathrm{kHz}$ and even more obvious under bridge mode (Fig. 2C). Twenty-nine motoneurons were tested with $8 \mathrm{kHz}$ or bridge mode, 19 in barbiturate-anesthetized mice and 10 in decerebrate (nonanesthetized) mice. Of these, 24 showed signs of oscillations (9/10 decerebrate, 15/19 barbiturate). The oscillations were more difficult to analyze in the preparations with higher excitability (i.e., decerebrate animals) because the synaptic noise was often increased.

Mixed mode oscillations were also observed in motoneurons in both anesthetized and decerebrate cats. Because the data of $4 / 5$ decerebrate cats originated from experiments in which only $3 \mathrm{kHz}$ switching frequency (DCC mode) was used, it was only possible to systematically analyze the features of this in the barbiturate-anesthetized cats. Here, the mean frequency of oscillations was $119.6 \mathrm{~Hz}$ ( $\pm 32.13 \mathrm{SD}, 20$ cells), which was not significantly different from that seen in the mouse $(p=$ 0.2851 , Fig. 2B).

\section{Summation of muscle twitches is minimal during the SPR in cat motor units at physiological temperatures}

For 18 medial gastrocnemius motoneurons (four barbiturateanesthetized cats), we performed simultaneous force recordings from the gastrocnemius muscle during the intracellular current ramp injections (Fig. 3A). Silver ball electrodes placed on the gastrocnemius muscle recorded the EMG activity from the muscle unit belonging to the recorded motoneuron. For these cells, force recordings were made with leg pool temperatures of 36$37^{\circ} \mathrm{C}$. The resulting force during the current ramp injection presented a bell-shaped curve with very little or no summation of single twitches occurring during the SPR, when the temperature of the leg oil pool was maintained at $37^{\circ} \mathrm{C}$. For each cell, the force reached at the transition point from the SPR to the primary range was measured and expressed as a percentage of the maximal force produced by that unit (if there was no summation then the amplitude of the single twitch was used). The mean force generated at the end of the SPR was $12.83 \%$ of maximal force (Fig. $3 B$ ). This mean was clearly affected by one outlier, with the median being more representative at $10.94 \%$ of maximal force. Linear regression showed no significant correlation between AHP duration and the proportion of maximal force obtained at the end of the 
A

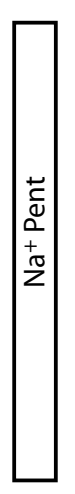

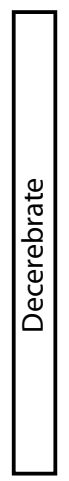

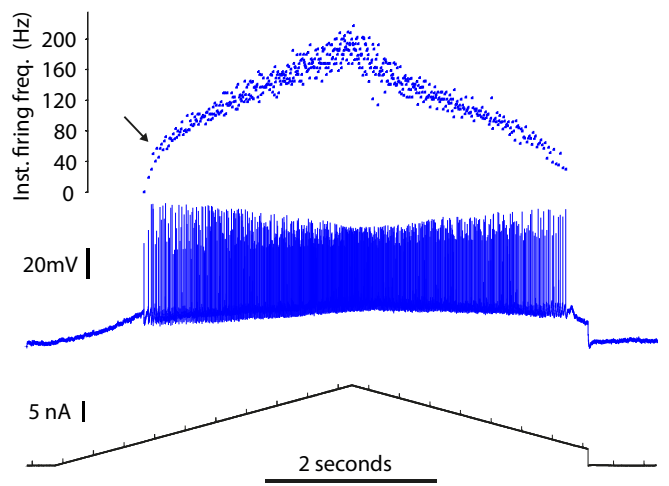

B
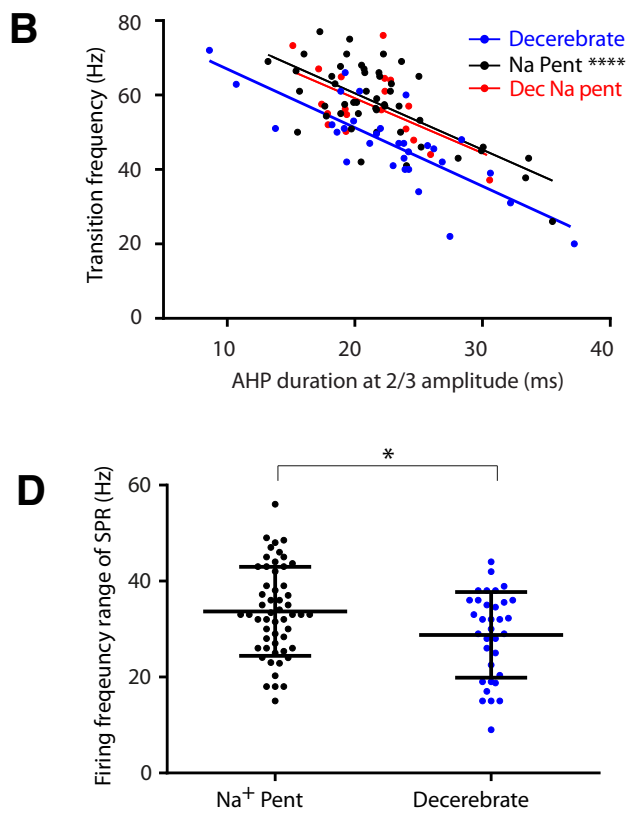
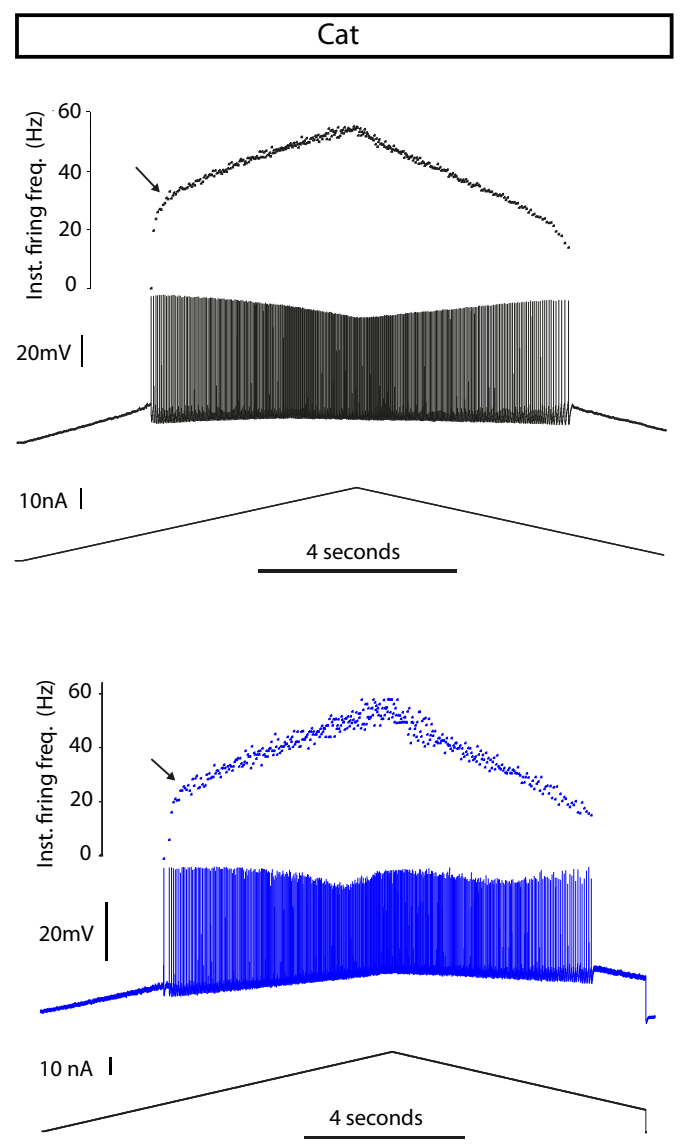

C
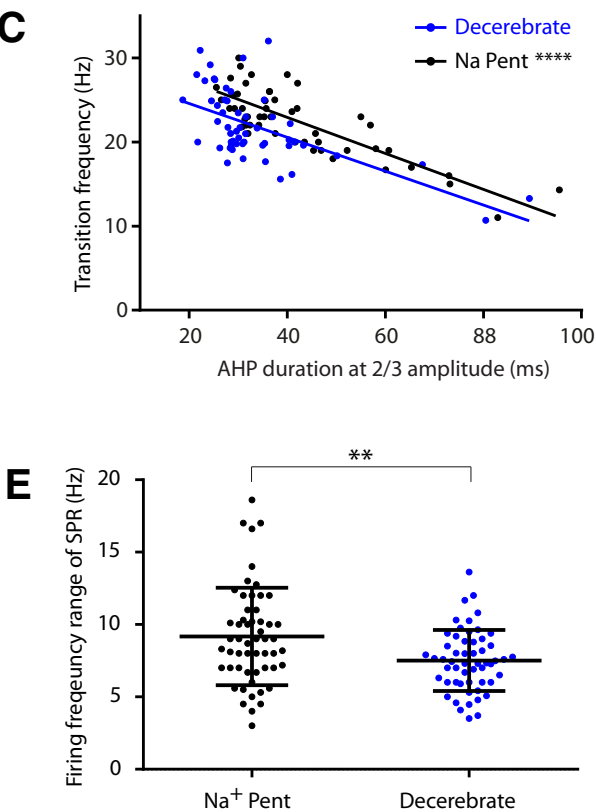

Figure 1. The SPR is enhanced by barbiturate anesthesia and is present in both mouse and cat motoneurons. $A$, Examples of repetitive firing recorded intracellularly (middle traces) and the instantaneous firing frequency (top traces) induced by a triangular current pulse (bottom traces). Recordings have been made in both mice (left column) and in cats (right column) in both barbiturate $\left(\mathrm{Na}^{+}\right.$pent) anesthetized (top column) and decerebrated (nonanesthetized) (bottom column) animals. An early steep increase in firing frequency consistent with the SPR is present in all four conditions. The transition between the SPR and the primary range is marked by arrows. B, Plot of the relationship between AHP duration measured at the return by $2 / 3$ of the amplitude and the firing frequency at which the transition from SPR to primary range occurs in decerebrated (blue) and barbiturate ( $\mathrm{Na}^{+}$pent) anesthetized (black) mice. Additional decerebrate micethat also received barbiturates are shown in red. C, Plot of the relationship between AHP duration measured at the return by $2 / 3$ of the amplitude and the firing frequency at which the transition from SPR to primary range occurs in decerebrated (blue) and barbiturate (Na ${ }^{+}$ pent) anesthetized (black) cat motoneurons. p-values are marked with asterisks next to the legend. $\boldsymbol{D}$, The frequency range of the SPR (SPR-primary range transition frequency minus the minimal firing frequency) for motoneurons from anesthetized and decerebrate mice. $\boldsymbol{E}$, The same data as in $\boldsymbol{D}$ but for cats. ${ }^{*} p \leq 0.05,{ }^{* *} p \leq 0.01,{ }^{* * * *} p \leq 0.0001$. 
Table 1. Statistical analysis of SPR transition zones in anesthetized and decerebrate (nonanesthetized) cats and mice

\begin{tabular}{|c|c|c|c|c|c|c|c|}
\hline Analysis & $\begin{array}{l}\text { Cells } \\
(n)\end{array}$ & $\begin{array}{l}\text { Animals } \\
(n)\end{array}$ & $\begin{array}{l}\text { Statistical } \\
\text { test }\end{array}$ & $\begin{array}{l}\text { Goodness } \\
\text { of fit }\left(R^{2}\right)\end{array}$ & $p$-value & $\begin{array}{l}\text { Are slopes significantly } \\
\text { different? }\end{array}$ & $\begin{array}{l}\text { Are elevation/intercepts of } \\
\text { slopes significantly different? }\end{array}$ \\
\hline $\begin{array}{l}\text { Barbiturate mice AHP vs SRP-primary } \\
\text { transition firing frequency }\end{array}$ & 48 & 7 & Linear regression & 0.4541 & $<0.0001$ & $\begin{array}{l}\text { No } \\
(P=0.8644)\end{array}$ & $\begin{array}{l}\text { Yes } \\
(P<0.0001)\end{array}$ \\
\hline $\begin{array}{l}\text { Decerebrate + barbiturate mice AHP vs } \\
\text { SRP-primary transition firing frequency }\end{array}$ & 19 & 4 & Linear regression & 0.3267 & $p=0.0106$ & $\begin{array}{l}\text { vs Barbiturate mice, } \\
\text { № }(P=0.9404)\end{array}$ & $\begin{array}{l}\text { vs Barbiturate mice, } \\
\text { № }(P=0.5558)\end{array}$ \\
\hline $\begin{array}{l}\text { Decerebrate cat AHP vs SRP-primary } \\
\text { transition firing frequency }\end{array}$ & 54 & 6 & Linear regression & 0.3713 & $<0.0001$ & $\begin{array}{l}\text { No } \\
(P=0.7578)\end{array}$ & $\begin{array}{l}\text { Yes } \\
(P=0.0001187)\end{array}$ \\
\hline
\end{tabular}

Table 2. Statistical analysis of duration of the SPR in anesthetized and decerebrate (nonanesthetized) mice and cats

\begin{tabular}{|c|c|c|c|c|c|c|c|}
\hline & $\begin{array}{l}\text { Cells } \\
(n)\end{array}$ & $\begin{array}{l}\text { Animals } \\
(n)\end{array}$ & Mean & SD & $\begin{array}{l}\text { Statistical } \\
\text { test }\end{array}$ & Test value & $p$ value \\
\hline $\begin{array}{l}\text { Barbiturate } \\
\text { mice }\end{array}$ & 53 & 7 & $33.69 \mathrm{~Hz}$ & 9.282 & \multirow[t]{2}{*}{$t$ test } & \multirow{2}{*}{$\begin{array}{l}t=2.445 \\
\mathrm{df}=86\end{array}$} & \multirow[t]{2}{*}{$p=0.0165$} \\
\hline $\begin{array}{l}\text { Decerebrate } \\
\text { mice }\end{array}$ & 34 & 7 & $28.80 \mathrm{~Hz}$ & 8.92 & & & \\
\hline $\begin{array}{l}\text { Barbiturate } \\
\text { cats }\end{array}$ & 55 & 5 & 9.174 & 3.371 & \multirow{2}{*}{$\begin{array}{l}\text { Mann- } \\
\text { Whitney }\end{array}$} & \multirow[t]{2}{*}{$U=1052$} & \multirow[t]{2}{*}{$p=0.0055$} \\
\hline $\begin{array}{l}\text { Decerebrate } \\
\text { cats }\end{array}$ & 55 & 6 & 7.516 & 2.112 & & & \\
\hline
\end{tabular}

These numbers include nine additional cells in which the SPR was observed but AHPs were not tested and therefore the cells were not included in the analyses in Table 1.

SPR, suggesting that the SPR plays a similar role in summation for both fast and slow motor units. It must be noted, however, that this sample of motoneurons was identified by stimulation of the medial gastrocnemius nerve and therefore consisted predominately of fast motor units.

If the leg pool was allowed to cool, however, more summation was observed during the SPR (Fig. 3C). In seven motoneurons, force measurements were made with the leg pool at three or more different temperatures from $37^{\circ} \mathrm{C}$ to $27^{\circ} \mathrm{C}$ (Fig. $3 \mathrm{C}$ ). In all but one cell (the green unit on Fig. $3 C$ ), the effect of decreasing the temperature of the oil pool was an increase in the maximum force generated during the SPR relative to the maximum force. The effect was most pronounced at $30^{\circ} \mathrm{C}$ or cooler, which in some cells almost obtained maximal summation (fused tetanic contractions) at the end of the SPR. The one motor unit not showing a change was only tested at $36^{\circ} \mathrm{C}, 34^{\circ} \mathrm{C}$, and $32^{\circ} \mathrm{C}$ and therefore most likely would have seen an increase if tested at colder temperatures. The range between units can most likely be explained by it being oil pool temperature that was measured and therefore there may be subtle differences in actual muscle fiber temperature depending on localization of the particular motor unit's muscle fibers within the muscle. The motor unit shown in red in Figure $3 C$, however, was affected by drops in temperature to as little as $34^{\circ} \mathrm{C}$. These recordings are shown in Figure $3 D$, where a change of only $3^{\circ} \mathrm{C}$ results in almost maximum force being generated during the SPR, somewhat reminiscent of the recent recordings published in mice (Manuel and Heckman, 2011). In the last cat, at the end of the experiment, the sciatic nerve was cut proximally and the distal stump stimulated at different frequencies and EMG and force measurements obtained from the gastrocnemius muscle. The results can be seen in Figure $3 E$, showing that cooling of the leg pool has drastic consequences for the amount of force generated during SPR frequencies.
The results that we present here when the leg oil pool is at $37^{\circ} \mathrm{C}$ in cat is very different from what has recently been reported in the mouse, but not, however, when the cat leg oil pool is at $30^{\circ} \mathrm{C}$ or colder. Therefore, we next investigated whether the discrepancy in the amount of force generation during the SPR between the two species can be partly explained by leg oil pool temperature during the recordings or if it represents a true species difference.

\section{Summation of muscle twitches during the SPR in the mouse is less than previously described}

In five barbiturate-anesthetized mice, the sciatic nerve was cut proximally, the distal stump was stimulated, and EMG and force measurements were made from the gastrocnemius muscle. From Figure 4, the effects of temperature on summation can be observed. When the leg pool temperature was maintained at $37^{\circ} \mathrm{C}$ at stimulation frequencies corresponding to the end of the SPR in anesthetized mice, only $42 \%$ of maximal force was achieved. Summation of individual twitches occurred on average at $30 \mathrm{~Hz}$ and fully fused tetanic contraction at $120 \mathrm{~Hz}$. If we are to assume that the frequency-force relationship is not affected by anesthesia, then at the mean end of the SPR in nonanesthetized mice $(47 \mathrm{~Hz})$, then this is closer to $\sim 30 \%$ of maximum force.

Due to the high surface to weight ratio of the mouse, it was difficult to maintain the leg pool temperature at $37^{\circ} \mathrm{C}$ without the use of a separate temperature probe in the leg oil pool and extra heat lamp aimed at the hindlimb oil pool. Removal of the additional heat lamp on the leg (i.e., only regulation of the core temperature to $37^{\circ} \mathrm{C}$ ) resulted in temperature of the leg oil pool of $30-32^{\circ} \mathrm{C}$. Recordings were therefore made at $32^{\circ} \mathrm{C}$. This significantly affected the relationship between stimulation frequency and the amount of summation (green trace on Fig. 4B), with summation of individual twitches occurring on average at 30 $\mathrm{Hz}$ and fully fused tetanic contractions at $100 \mathrm{~Hz}$ at $32^{\circ} \mathrm{C}$. At stimulation frequencies corresponding to the mean end of the SPR, $\sim 63 \%$ of maximal force was now achieved. Further cooling to $25^{\circ} \mathrm{C}$ by the addition of cold paraffin oil to the oil pool resulted in even more drastic changes (blue trace) with the summation of individual twitches, on average at $20 \mathrm{~Hz}$, and fully fused tetanic contractions at $70 \mathrm{~Hz}$. Stimulation frequencies corresponding to the mean end of the SPR now produced $\sim 88 \%$ of maximal force. These changes were consistent across all five mice that were tested at intervals from 10 to 120 $\mathrm{Hz}$ and the frequency-percentage maximal force curves at the different temperatures were all statistically significantly different from one another $(p=0.0004$, repeated-measures ANOVA, Table 3 ). As a result of this, the stimulation frequencies at which summation started to occur were significantly 
A
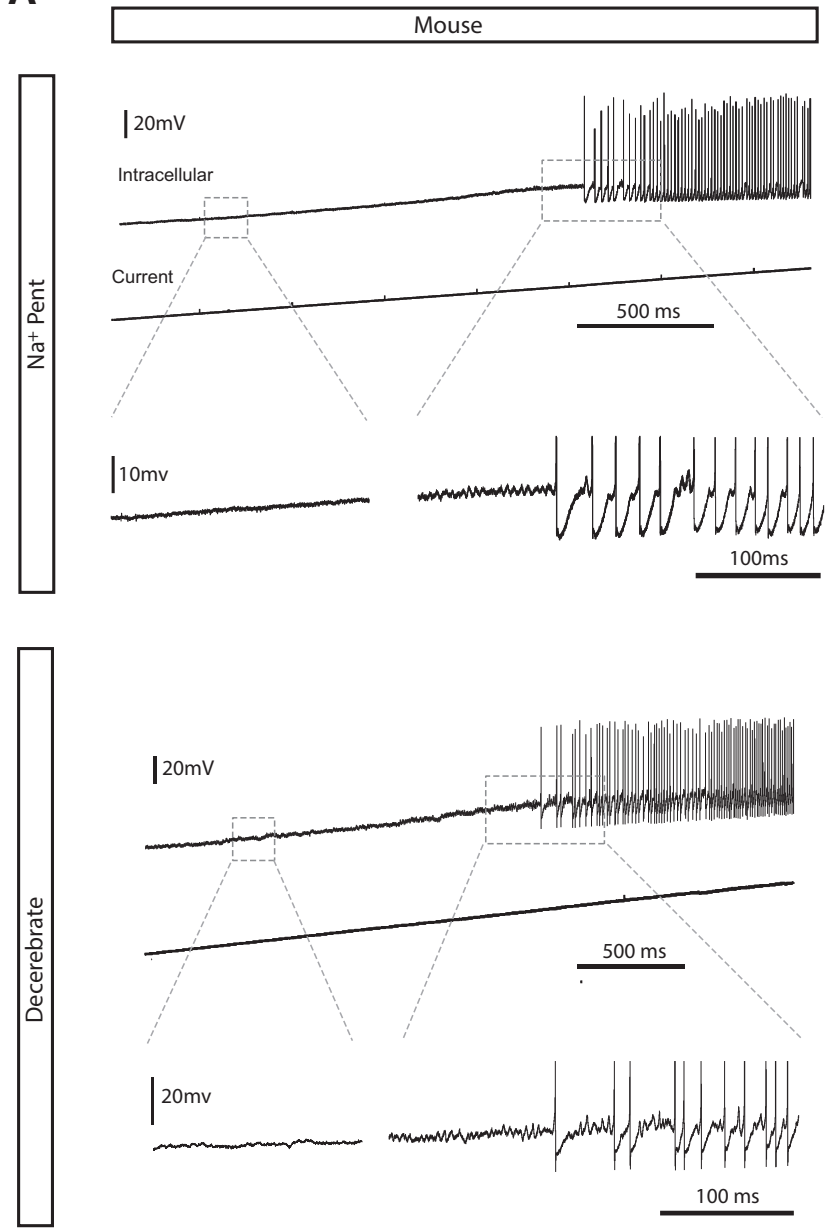

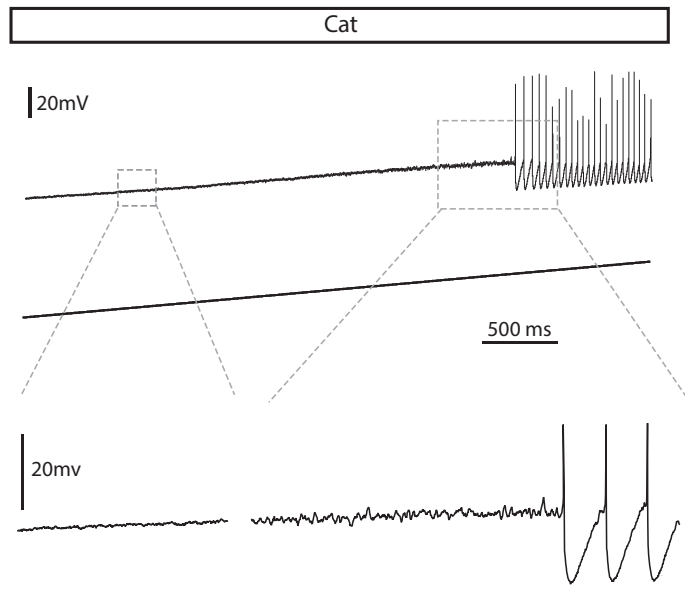

$100 \mathrm{~ms}$

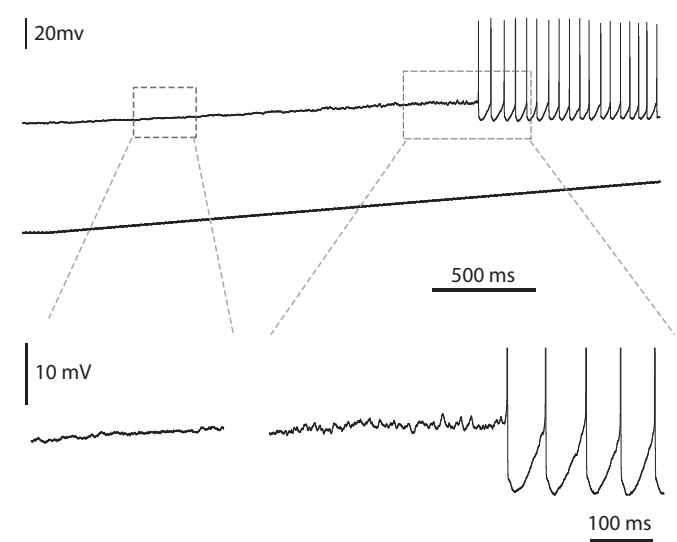

B

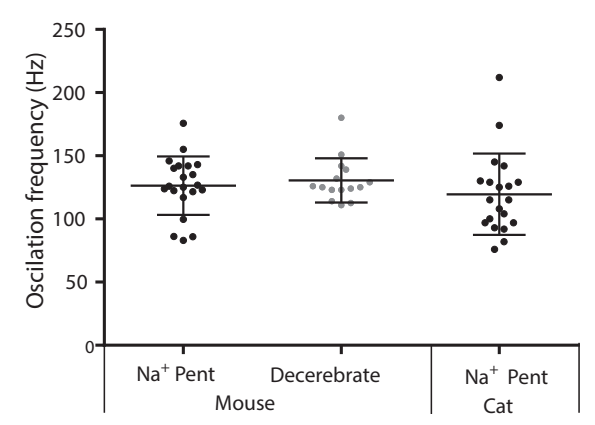

C

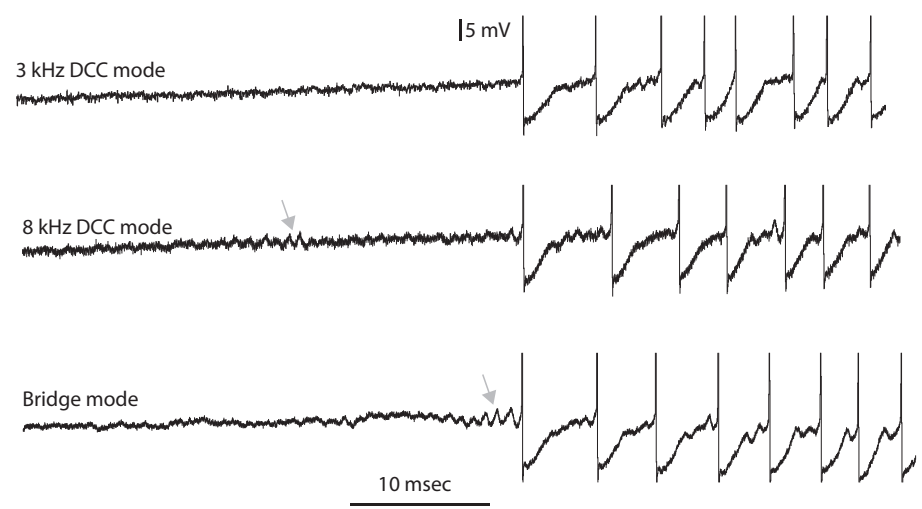

Figure 2. MMOs are present in both mouse and cat motoneurons. $A$, Examples of MMOs in mice (top column) and in cats (bottom column) in both barbiturate ( $\mathrm{Na}{ }^{+}$Pent) anesthetized (top row) and decerebrated (bottom row) animals. The top traces for each show the voltage response to an intracellular current injection (middle traces). Magnification of voltage responses in the dashed boxes is shown in the bottom traces (spikes are truncated) with small oscillations starting just below spike threshold. $\boldsymbol{B}$, Dot plot of the frequency of oscillations starting subspike threshold in barbiturate $\left(\mathrm{Na}{ }^{+}\right.$Pent) anesthetized mice, decerebrated mice, and barbiturate $\left(\mathrm{Na}^{+}\right.$Pent) anesthetized cats. C, Examples of the voltage response to a current ramp in the same motoneuron in a mouse recorded with a DCC switching frequency of $3 \mathrm{kHz}$ (top trace), $8 \mathrm{kHz}$ (middle trace) or in bridge mode (bottom trace). Arrows indicate the small oscillations immediately subthreshold.

Table 3. Statistical analysis of oscillation frequency in anesthetized and decerebrate (nonanesthetized) mice and anesthetized cats

\begin{tabular}{llllllll}
\hline & $\begin{array}{l}\text { Cells } \\
(n)\end{array}$ & $\begin{array}{l}\text { Animals } \\
(n)\end{array}$ & Mean & SD & $\begin{array}{l}\text { Statistical } \\
\text { test }\end{array}$ & $\begin{array}{l}\text { Test } \\
\text { value }\end{array}$ & $p$-value \\
\hline Barbiturate mice & 21 & 7 & 126.3 & 23.13 & & & \\
Decerebrate mice & 15 & 7 & 130.4 & 17.5 & Kruskal- & 2.510 & $p=0.2851$ \\
Barbiturate cats & 20 & 5 & 119.6 & 32.13 & Wallis & & \\
\hline
\end{tabular}

lower at colder temperatures $(p=0.0123)$, with the post hoc test showing this is due to significant differences between $37^{\circ} \mathrm{C}$ and $25^{\circ} \mathrm{C}$ ( $p=0.0342$, Fig. $4 C$, Table 4$)$. Similarly, stimulation frequencies at which a fully fused tetanus occurred were also significantly lower at colder temperatures, with the post hoc test showing the main difference between $37^{\circ} \mathrm{C}$ and $25^{\circ} \mathrm{C}(p=$ 0.0047 , Fig. $4 D$, Table 3 ). 
A

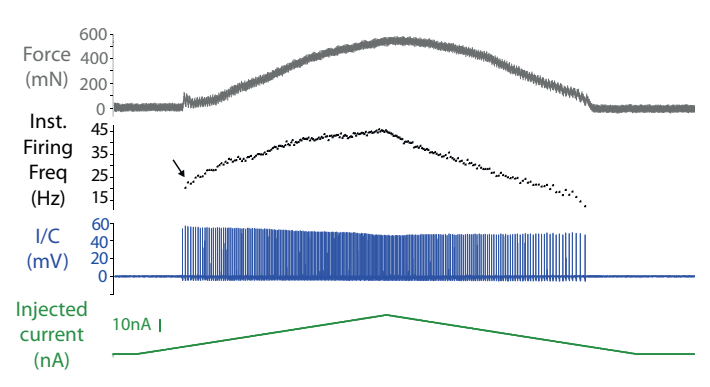

D
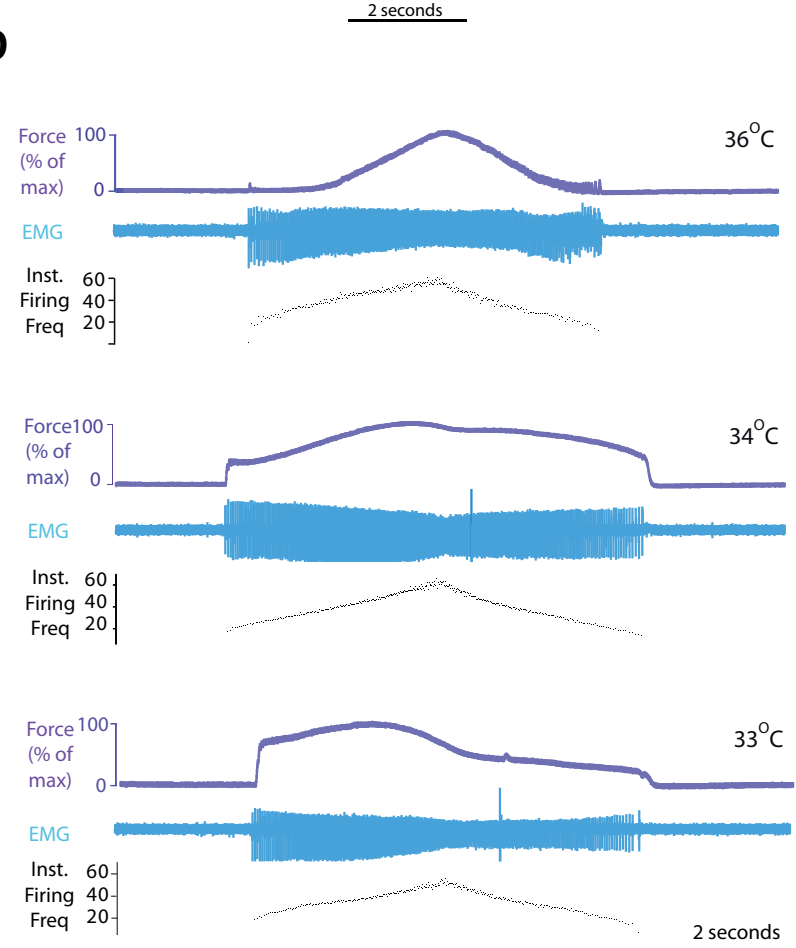

B

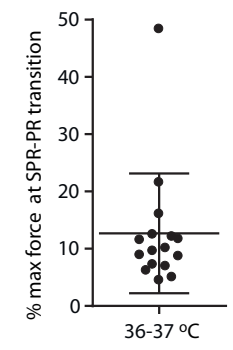

C

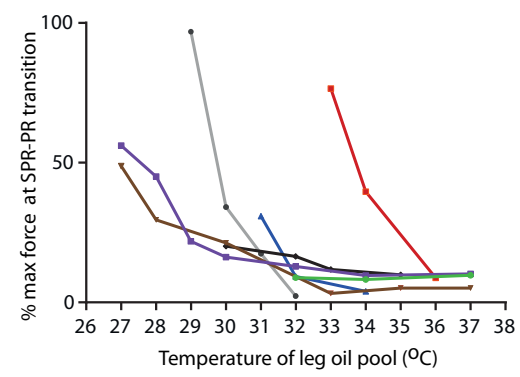

E
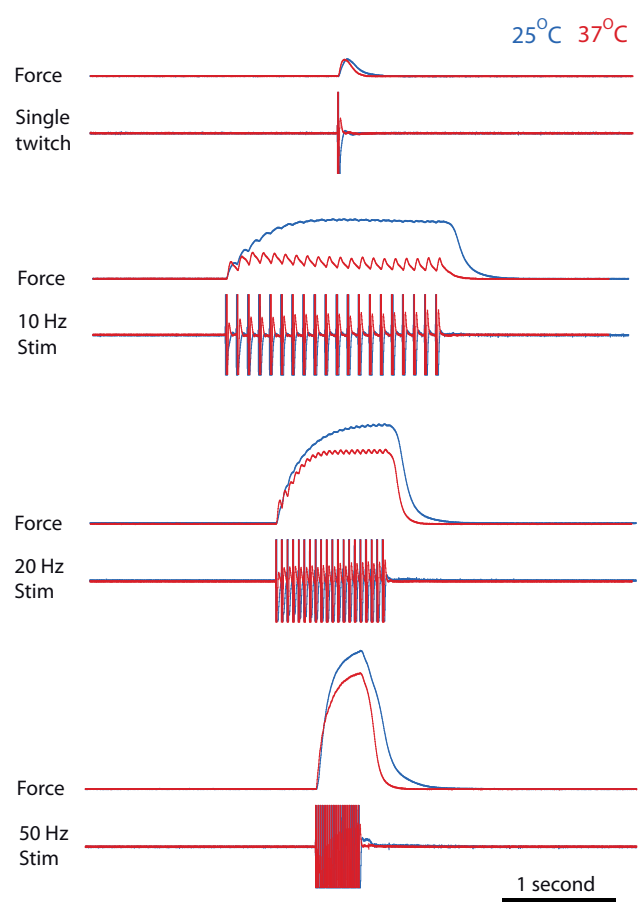

Figure 3. Force production in response to intracellular current injection in the cat. $\boldsymbol{A}$, Example of the force generated (top trace, gray) in a cat gastrocnemius motor unit in response to an intracellular ramp current injection (bottom trace, green) causing repetitive firing by the motoneuron (blue trace). The SPR is indicated by an arrow on the instantaneous firing frequency. From this, it can be observed that there is very little summation of force during the SPR frequencies. $B$, Dot plot showing the force reached at the transition point from the SPR to the primary range for individual motor units expressed as a percentage of the maximal force produced by that unit. $C$, Line chart showing the force reached at the transition point from the SPR to the primary range for individual motor units (indicated by different colors) measured with the leg oil pool at different temperatures. $\boldsymbol{D}$, Example of force production for the gastrocnemius motor unit marked in red in $\boldsymbol{C}$ during ramp current injections with the leg oil pool at three different temperatures. The top traces (purple) are the changes in force resulting from increases in the instantaneous firing frequencies (lower black traces). Here, it can be seen that a cooling of the muscle results in almost maximal force during the initial short SPR. The similarity of the simultaneous EMG recordings (middle traces, blue) show that the results cannot be explained by differences in the conduction of the signals at the motor endplate. $\boldsymbol{E}$, Force production of gastrocnemius muscle (top traces) and surface EMG (bottom traces) in response to nerve stimulation in the cat. Examples depict recordings of a single twitch and of stimulation frequencies of 10,20 , and $50 \mathrm{~Hz}$ with the leg oil pool temperature at $37^{\circ} \mathrm{C}\left(\right.$ red lines) and $25^{\circ} \mathrm{C}$ (blue lines).

From the curves in Figure 4E, it can be seen that the effect of temperature cannot simply be explained by a reduction in the absolute maximum tetanic force. Although maximum force was affected by temperature $(p=0.0239$, Table 4$)$, post hoc tests showed no significant difference in maximum force between $37^{\circ} \mathrm{C}$ and $25^{\circ} \mathrm{C}$ (although it did drop in some mice); however, there was an significant increase in maximal force at $32^{\circ} \mathrm{C}$ compared with $37^{\circ} \mathrm{C}(p=0.0343)$.

To explore whether the increased summation was due to changes in individual muscle twitches, single twitches were recorded (using $0.05 \mathrm{~Hz}$ stimulation frequency) in 7 mice (including the above 5 animals from which data are shown in Figure 4 and 2 additional mice in which not all frequencies had been tested). Examples of twitches from the same mice at different temperatures are shown in Figure $5 A$. From this, the effects of temperatures are apparent in that cooling of the muscle significantly increases the amplitude of the individual muscle twitch $(p=0.0003$, Friedman, Fig. $5 B$ ). Post hoc tests (Dunn's multiple comparisons) confirmed significant differences between $37^{\circ} \mathrm{C}$ and $25^{\circ} \mathrm{C}(p=0.0226)$. Cooling of the muscle also significantly increased twitch duration measured at half-amplitude $(p=$ 0.0002, Friedman test, Fig. 5C). Post hoc tests (Dunn's multiple comparisons) confirmed significant differences between $37^{\circ} \mathrm{C}$ and $25^{\circ} \mathrm{C}(p=0.0005)$ and a trend between $37^{\circ} \mathrm{C}$ and $32^{\circ} \mathrm{C}(p=$ $0.0781)$. This increase in width was due to both a significant increase in time to peak ( $p=0.0002$ Friedman test, Fig. $5 D)$ and $1 / 2$ relaxation time ( $p=0.0003$ Friedman test, Fig. $5 E)$ with muscle cooling. 
A

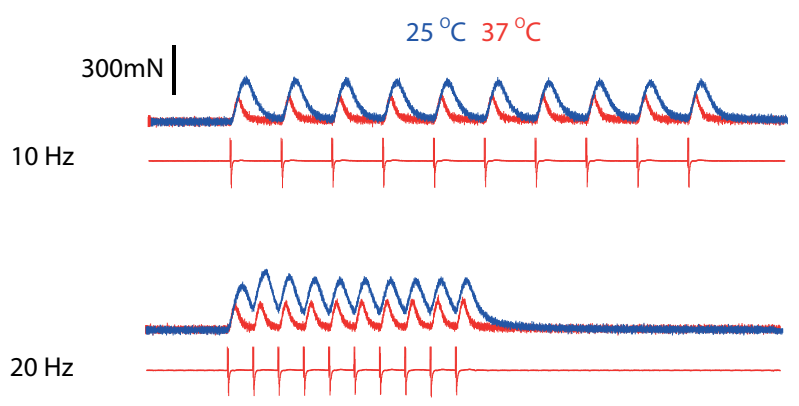

$30 \mathrm{~Hz}$

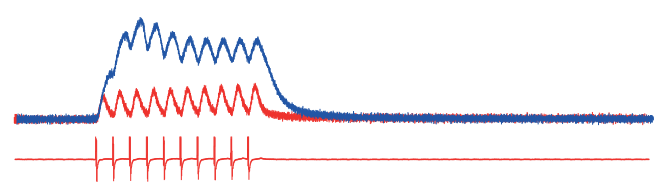

$40 \mathrm{~Hz}$

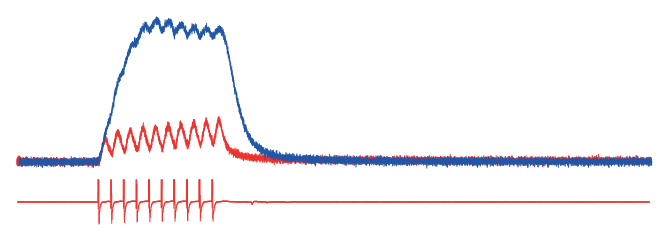

$50 \mathrm{~Hz}$

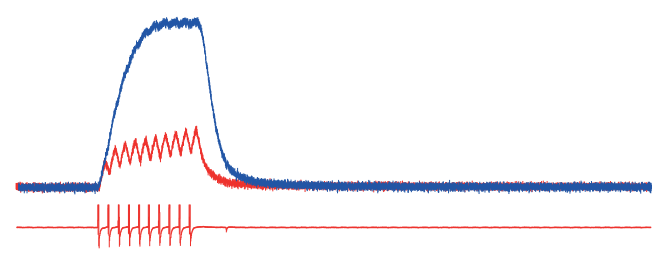

$100 \mathrm{~Hz}$

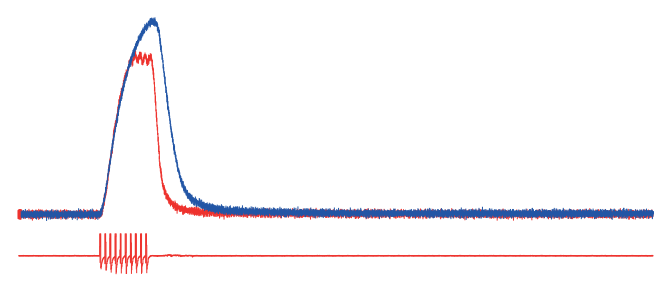

$120 \mathrm{~Hz}$

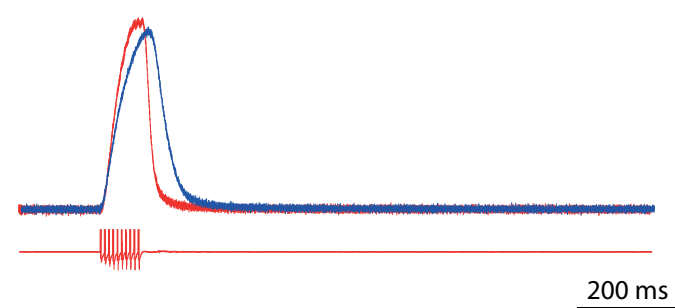

B

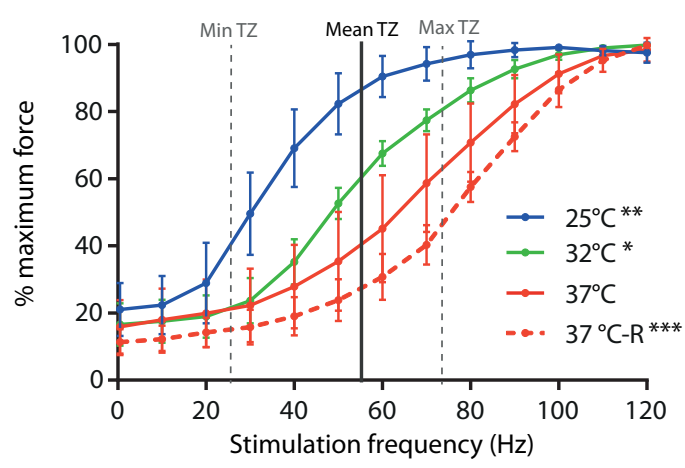

C

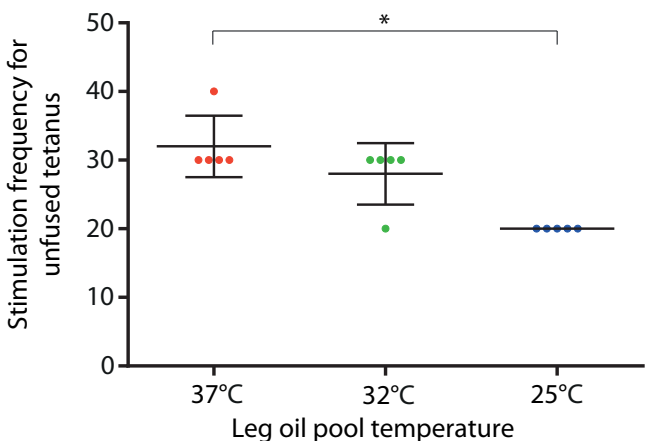

D

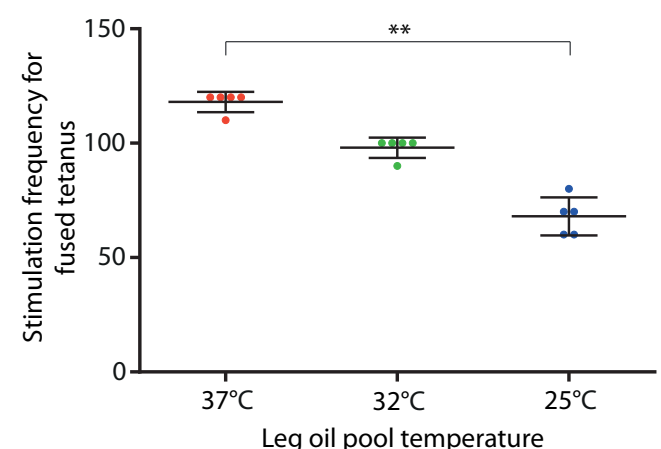

E

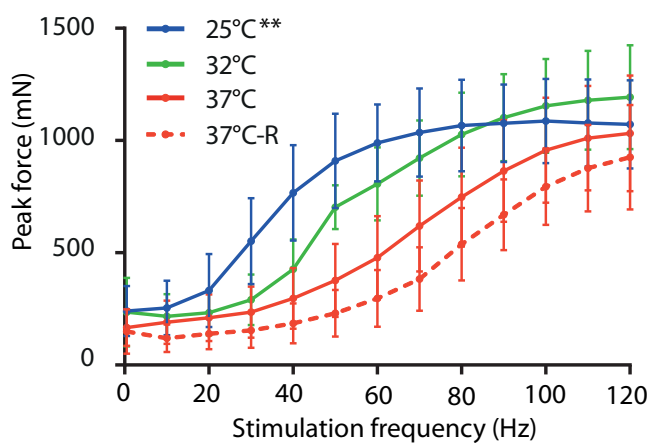

Figure 4. Force produced during the SPR is dependent on temperature in mice. $A$, Force production in mouse gastrocnemius muscle (top traces) and surface EMG (bottom traces) in response to nerve stimulation at different frequencies. Examples are shown of stimulation frequencies within the $S P R(10-50 \mathrm{~Hz}), 100 \mathrm{~Hz}$, and $120 \mathrm{~Hz}$. Recordings were made with the leg oil pool at a temperature of $37^{\circ} \mathrm{C}$ (red lines) and $25^{\circ} \mathrm{C}$ (blue lines). B, Plot of the percentage of maximum force at different stimulation frequencies in mice with leg oil pool temperatures of $37^{\circ} \mathrm{C}\left(\right.$ red line), $32^{\circ} \mathrm{C}$ (green line), $25^{\circ} \mathrm{C}$ (blue line), and reheated to $37^{\circ} \mathrm{C}$ at the end of the protocol (dashed red line, $37^{\circ} \mathrm{C}-\mathrm{R}$ ). The mean firing frequency at which the transition from the SPR to primary range occurs is indicated by the black vertical line and broken lines indicate the maximum and minimum transition zones (TZ) observed. C, Plot of the lowest stimulation frequency at which the twitches in the muscle started to summate with leg oil pool temperatures of $37^{\circ} \mathrm{C}$ (red dots), $32^{\circ} \mathrm{C}$ (green dots), and $25^{\circ} \mathrm{C}$ (blue dots). D, Plot of the lowest stimulation frequency at which the muscle produced a fused tetanus at leg oil pool temperatures of $37^{\circ} \mathrm{C}\left(\mathrm{red}\right.$ dots), $32^{\circ} \mathrm{C}$ (green dots), and $25^{\circ} \mathrm{C}$ (blue dots). $\boldsymbol{E}$, Plot of the absolute peak force at different stimulation frequencies with leg oil pool temperatures of $37^{\circ} \mathrm{C}$ (red line), $32^{\circ} \mathrm{C}$ (green line), $25^{\circ} \mathrm{C}$ (blue line), and reheated to $37^{\circ} \mathrm{C}$ at the end of the protocol (dashed red line $\left.37^{\circ} \mathrm{C}-\mathrm{R}\right) .{ }^{*} p \leq 0.05,{ }^{* *} p \leq 0.01,{ }^{* * *} p \leq 0.001$. 
Table 4. Statistical analysis of force measurements in mice

\begin{tabular}{|c|c|c|c|c|c|c|c|}
\hline Analysis & Animals $(n)$ & Statistical test & $\begin{array}{l}\text { Fvalue/Friedman } \\
\text { statistic }\end{array}$ & $p$ value & Post hoc test & Comparison & $p$-value \\
\hline \multirow{6}{*}{$\begin{array}{l}\text { Percentage of maximal force at different } \\
\text { stimulation frequency at different temperatures }\end{array}$} & \multirow[t]{6}{*}{5} & \multirow{6}{*}{$\begin{array}{l}\text { Repeated-measures } \\
\text { ANOVA }\end{array}$} & \multirow[t]{6}{*}{18.89} & \multirow[t]{6}{*}{0.0004} & \multirow{6}{*}{$\begin{array}{l}\text { Tukey's multiple } \\
\text { comparisons }\end{array}$} & 37 vs 32 & 0.0212 \\
\hline & & & & & & 37 vs 25 & 0.0057 \\
\hline & & & & & & 37 vs 37 revisited & 0.0010 \\
\hline & & & & & & 32 vs 25 & 0.0123 \\
\hline & & & & & & 32 vs 37 revisited & 0.0047 \\
\hline & & & & & & 24 vs 37 revisited & 0.0028 \\
\hline \multirow{6}{*}{$\begin{array}{l}\text { Absolute force at different stimulation } \\
\text { frequencies at different temperatures }\end{array}$} & \multirow[t]{6}{*}{5} & \multirow{6}{*}{$\begin{array}{l}\text { Repeated-measures } \\
\text { ANOVA }\end{array}$} & \multirow[t]{6}{*}{13.64} & \multirow[t]{6}{*}{0.0023} & Tukey's multiple & 37 vs 32 & 0.1633 \\
\hline & & & & & comparisons & 37 vs 25 & 0.0035 \\
\hline & & & & & & 37 vs 37 revisited & 0.2888 \\
\hline & & & & & & 32 vs 25 & 0.9515 \\
\hline & & & & & & 32 vs 37 revisited & 0.0256 \\
\hline & & & & & & 24 vs 37 revisited & 0.0011 \\
\hline \multirow{3}{*}{$\begin{array}{l}\text { Stimulation frequency when twitches start } \\
\text { to summate at different temperatures }\end{array}$} & \multirow[t]{3}{*}{5} & \multirow[t]{3}{*}{ Friedman test } & \multirow[t]{3}{*}{8.375} & \multirow[t]{3}{*}{0.0123} & Dunn's multiple & 37 vs 32 & 0.9999 \\
\hline & & & & & comparisons & 37 vs 25 & 0.0342 \\
\hline & & & & & & 32 vs 25 & 0.2460 \\
\hline \multirow{3}{*}{$\begin{array}{l}\text { Stimulation frequency when fused tetanus } \\
\text { occured at different temperatures }\end{array}$} & \multirow[t]{3}{*}{5} & \multirow[t]{3}{*}{ Friedman test } & \multirow[t]{3}{*}{10.00} & \multirow[t]{3}{*}{0.0008} & Dunn's multiple & 37 vs 32 & 0.3415 \\
\hline & & & & & comparisons & 37 vs 25 & 0.0047 \\
\hline & & & & & & 32 vs 25 & 0.3415 \\
\hline \multirow[t]{6}{*}{ Force of single twitches } & \multirow[t]{6}{*}{7} & \multirow[t]{6}{*}{ Friedman test } & 18.94 & 0.0003 & Dunn's multiple & 37 vs 32 & 0.3746 \\
\hline & & & & & comparisons & 37 vs 25 & 0.0226 \\
\hline & & & & & & 37 vs 37 revisited & 0.9999 \\
\hline & & & & & & 32 vs 25 & 0.9999 \\
\hline & & & & & & 32 vs 37 revisited & 0.0225 \\
\hline & & & & & & 24 vs 37 revisited & 0.0005 \\
\hline Width of single twitches at $1 / 2$ amplitude & 7 & Friedman test & 19.29 & 0.0002 & Dunn's multiple & 37 vs 32 & 0.0781 \\
\hline & & & & & comparisons & 37 vs 25 & 0.0005 \\
\hline & & & & & & 37 vs 37 revisited & 0.9999 \\
\hline & & & & & & 32 vs 25 & 0.8838 \\
\hline & & & & & & 32 vs 37 revisited & 0.3746 \\
\hline & & & & & & 24 vs 37 revisited & 0.0056 \\
\hline Time to peak of single twitches & 7 & Friedman test & 19.87 & 0.0002 & Dunn's multiple & 37 vs 32 & 0.4708 \\
\hline & & & & & comparisons & 37 vs 25 & 0.0080 \\
\hline & & & & & & 37 vs 37 revisited & 0.9999 \\
\hline & & & & & & 32 vs 25 & 0.8838 \\
\hline & & & & & & 32 vs 37 revisited & 0.0580 \\
\hline & & & & & & 24 vs 37 revisited & 0.0003 \\
\hline Time to $1 / 2$ relaxation & 7 & Friedman test & 18.94 & 0.0003 & Dunn's multiple & 37 vs 32 & 0.1366 \\
\hline & & & & & comparisons & 37 vs 25 & 0.0012 \\
\hline & & & & & & 37 vs 37 revisited & 0.9999 \\
\hline & & & & & & 32 vs 25 & 0.8838 \\
\hline & & & & & & 32 vs 37 revisited & 0.2306 \\
\hline & & & & & & 24 vs 37 revisited & 0.0026 \\
\hline
\end{tabular}

\section{Discussion}

The results of the current study demonstrate that the SPR is not restricted to rodent motoneurons, but is also a feature of the $I-f$ slopes of cat motoneurons. The range itself is relatively short, quickly traversed, and little summation of muscle twitches occurs during this period in the cat. In both cats and mice, the SPR is significantly enhanced by the use of barbiturate anesthesia. Although it is true that more force is generated during the SPR in mice than cats, we were unable to confirm earlier reports of near maximal tetanic contractions during SPR frequencies and our results show that, when muscle temperature is carefully controlled, much less force is produced at these frequencies than was previously described.

\section{Why was the SPR overlooked in cat?}

Based on our results, we propose that the SPR has previously been ignored or missed in the cat for the following reasons. First, the range of currents resulting in the SPR is brief. In the first experiments defining the $I-f$ slopes in cats, square pulses were used with progressively increasing current steps (Granit et al., 1963), which would have rapidly traversed the SPR with the large current steps. Also, due to spike frequency adaptation, it is likely that firing in the earlier portion of the SPR would not be maintained as steadystate firing. Next, due to the effects of anesthetic on ionic conductances that influence the $I-f$ slope (e.g., persistent inward currents; Guertin and Hounsgaard, 1999; Button et al., 2006), much of the subsequent investigation has involved the use of nonanesthetized, decerebrate cats in which the SPR has a much more narrow range and thus is even more easily traversed. Ramp speed is also important and it is worth noting that the ramp speeds used by Manuel et al. (2009) in mouse $(0.5 \mathrm{nA} / \mathrm{s})$ are much slower than has previously been used in cat (Lee and Heckman, 1998; Krawitz et al., 2001; Wienecke et al., 2009; Brownstone et al., 2011), which would prolong the time spent in the SPR.

Mixed mode oscillations may not have been recognized earlier due to the focus on what happens to the membrane potential after the motoneuron produces an action potential. These oscillations are most prominent before a spike train. In our experiments, the 
A

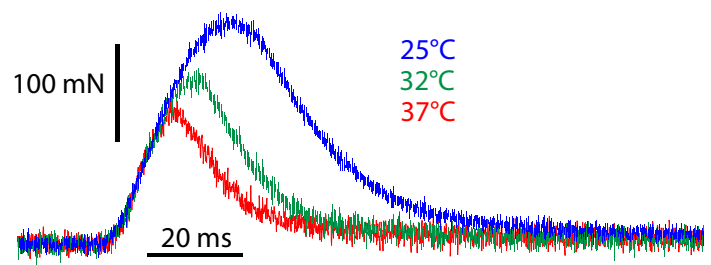

B

D
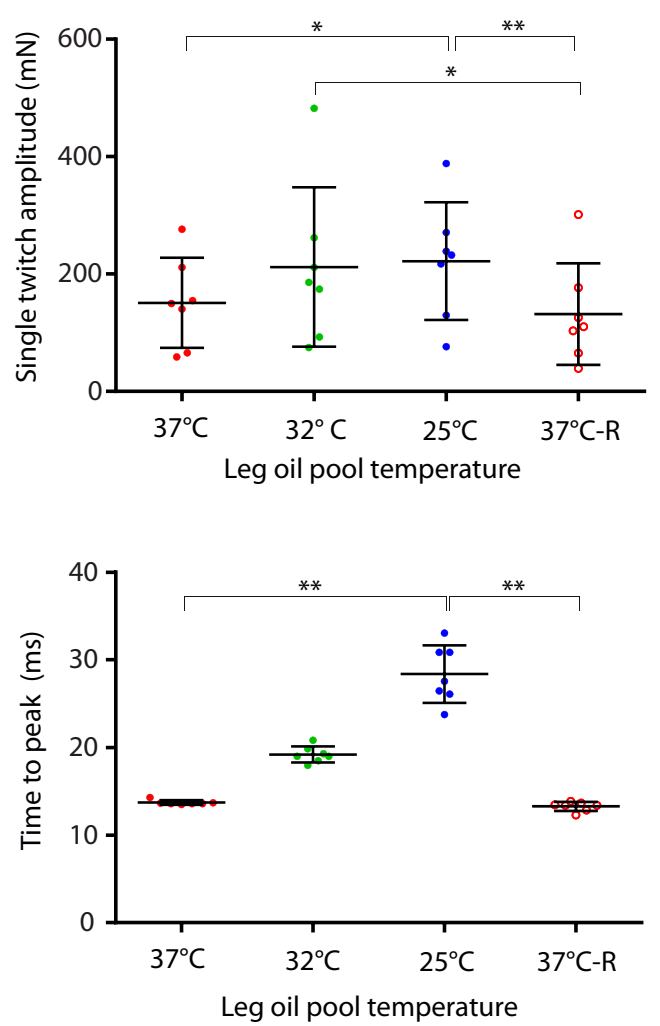

C

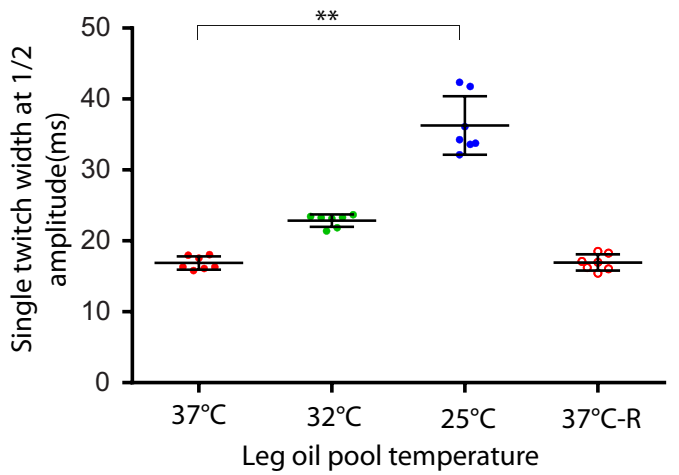

$\mathbf{E}$

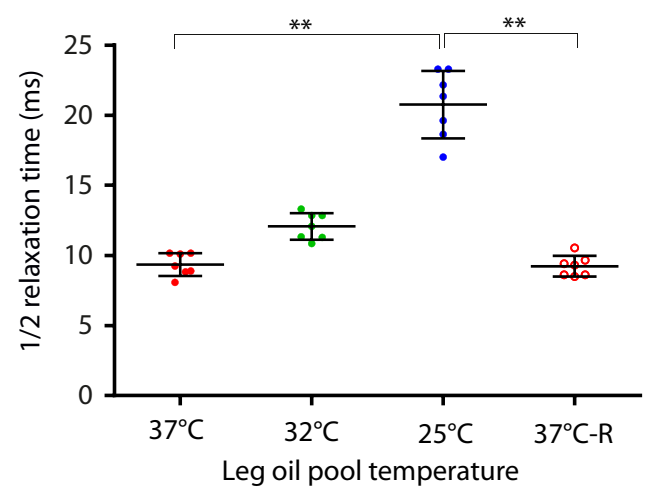

Figure 5. Twitch properties at different temperatures. $A$, Examples of single twitches recorded at leg oil pool temperatures of $37^{\circ} \mathrm{C}$ (red line), $32^{\circ} \mathrm{C}$ (green line), and $25^{\circ} \mathrm{C}(\mathrm{blue} \mathrm{line).} B$, Dot plot of the single twitch amplitude at leg oil pool temperatures of $37^{\circ} \mathrm{C}, 32^{\circ} \mathrm{C}, 25^{\circ} \mathrm{C}$, and $37^{\circ} \mathrm{C}$ reheated $\left(37^{\circ} \mathrm{R}\right)$. C, Dot plot of the twitch width measured at $1 / 2$ the maximal amplitude at leg oil pool temperatures of $37^{\circ} \mathrm{C}, 32^{\circ} \mathrm{C}, 25^{\circ} \mathrm{C}$, and $37^{\circ} \mathrm{C}-\mathrm{R}$ (reheated). D, Dot plot of the time to peak for a single muscle twitch at leg oil pool temperatures of $37^{\circ} \mathrm{C}, 32^{\circ} \mathrm{C}, 25^{\circ} \mathrm{C}$, and $37^{\circ} \mathrm{C}-\mathrm{R}($ reheated). $\boldsymbol{E}$, Dot plot of the time taken for the force to return to $1 / 2$ amplitude at leg oil pool temperatures of $37^{\circ} \mathrm{C}, 32^{\circ} \mathrm{C}, 25^{\circ} \mathrm{C}$, and $37^{\circ} \mathrm{C}-\mathrm{R}$ (reheated). ${ }^{*} p \leq 0.05,{ }^{* *} p \leq 0.01$.

MMOs were most easily detected when recording in bridge mode or DCC recordings at higher rates. The DCC rate represents how often the electrode switches from injecting current to recording. If we use $130 \mathrm{~Hz}$ as the typical frequency of the MMOs as an example, then by using DCC mode at $3 \mathrm{kHz}, \sim 23$ membrane potential samples would be collected over the period covering an oscillation. However, by using an $8 \mathrm{kHz}$ switching rate, $\sim 61 \mathrm{sam}-$ ples would be collected during that same period. It is thus obvious that with $3 \mathrm{kHz}$ the peaks and troughs of the MMOs are often missed. During the DCC mode, there is also a higher noise level than in the bridge mode, which would also contribute to the difficulty to record the MMOs. Also, in decerebrate preparations, we observed that the high background synaptic noise can often mask the oscillations. It is also possible that MMOs and the SPR were noticed in earlier studies (SPRs can be seen in figures in previously published papers), but were not thought to be very important for significant force generation under normal physiological conditions.
Muscle temperature influences the amount of summation achieved during the SPR due to its effects on muscle twitch dynamics in both cat and mouse

In our mouse experiments, when an additional heating system was not specifically used for the leg oil pool, the temperature of the leg pool fell to between $30^{\circ} \mathrm{C}$ and $32^{\circ} \mathrm{C}$. Differences in the temperature of leg muscles during recording may therefore have contributed to the previously reported differences in muscle twitch dynamics between cats and mice because mice are extremely vulnerable to peripheral heat loss due to their high surface to weight ratio. Given that, in the previous SPR muscle force experiments described in mice (Manuel and Heckman, 2011, 2012), only core temperature was maintained at $38^{\circ} \mathrm{C}$, this could help to explain their results of near maximal tetanic force during the SPR. In the current experiments, only by cooling the muscle to $25^{\circ} \mathrm{C}$ were we able replicate those findings (Manuel and Heckman, 2011), with stimulation frequencies corresponding to the mean end of the SPR producing $88 \%$ of maximal force. 
In vitro experiments of both isolated mouse muscle fibers (from flexor digitorum brevis) and whole EDL muscles have previously shown that the amplitude of maximal isometric tetanic contractions were not significantly different when cooling the muscle from $35^{\circ} \mathrm{C}$ to $25^{\circ} \mathrm{C}$. However, the stimulation frequencies necessary to obtain tetanic contraction at $25^{\circ} \mathrm{C}$ were significantly reduced to approximately half of that used at $35^{\circ} \mathrm{C}$ (Lännergren and Westerblad, 1987; Faulkner et al., 1990), which is consistent with our in vivo results. This is a consequence of the increase in both rise time and relaxation time of the individual twitches that we observed, which allow them to summate at lower frequencies. Similar effects on twitches have also been shown in vitro, where progressive cooling of murine EDL and soleus muscles from $30^{\circ} \mathrm{C}$ to $10^{\circ} \mathrm{C}$ also resulted in a slowing of the time to peak and halfrelaxation time of single twitches (Ranatunga, 1980; Gordon and Stein, 1985; Lännergren and Westerblad, 1987). The mechanisms underlying these changes are thought to be due to changes in ATPase activity at different temperatures, which influences the rate of $\mathrm{Ca}^{2+}$ binding and so results in a change in the rate of force development (Brenner and Eisenberg, 1986). At cold temperatures, slower ATP binding results in a slower detachment of myosin heads (Faulkner et al., 1990) and a slower reuptake of $\mathrm{Ca}^{2+}$ (Kössler and Küchler, 1987; Kössler et al., 1987), which would explain the increase in relaxation time of single twitches that we observed with muscle cooling.

A prolongation of the duration of individual muscle twitches resulting in increases in the summation of twitches during nerve stimulation has been observed in mouse models of the neurodegenerative disease amyotrophic lateral sclerosis (ALS) (Dibaj et al., 2015), although whether the mechanisms by which this occurs are similar to that occurring during cooling are not known. Reductions in the sarcoplasmic/endoplasmic reticulum $\mathrm{Ca}^{2+}$ ATPase proteins SERCA1 and SERCA2 have been shown in the same ALS model (Chin et al., 2014), suggesting that the underlying mechanisms may be similar. Interestingly, AHP duration is also increased in ALS mice at symptom onset (Maglemose et al., 2017), which suggests that the motor unit seems to homeostatically adjust itself to maintain the relationship between AHP duration and summation of muscles twitches.

\section{Physiological relevance of the SPR}

Our results clearly demonstrate that the SPR of firing is not restricted to rodents. The functional relevance is not only related to the amount of force generated during the SPR, but also depends on the degree to which activating the motoneuron with slow ramps of current injection actually reflects the behavior of synaptically driven motoneuron firing in a physiological setting.

Using intracellular current injection to the soma, the current reaches the spike-generating region, the axon initial segment, before causing a significant depolarization in the dendritic tree. In the dendrites, the injected current activates dendritic L-type $\mathrm{Ca}^{2+}$ channels, which amplify the inputs, causing the secondary range of firing (Schwindt and Crill, 1982; Hounsgaard and Kiehn, 1989; Bui et al., 2006). The majority of synaptic inputs to motoneurons (at least 95\%) are on the dendritic tree (Rose, 1981; Cullheim et al., 1987; Fyffe, 1991; Grande et al., 2005; Montague et al., 2013; Rotterman et al., 2014; Maratta et al., 2015). Under physiological conditions with synaptic excitation, the L-type $\mathrm{Ca}^{2+}$ channels would therefore actually be activated at subspike threshold (Bennett et al., 1998; Hultborn et al., 2003), thereby most likely eliminating both the SPR and primary range.

So to what extent do motoneurons use SPR frequencies? During fictive locomotion evoked by L-DOPA administration in de- cerebrated mice, we have previously observed firing frequencies on average $\sim 177 \mathrm{~Hz}$ (median $142 \mathrm{~Hz}$, which falls well outside of the SPR of frequencies) in motoneurons from tibial, gastrocnemius, or common peroneal identified motoneurons during the active phase of the corresponding nerve. The firing in the active phase often starts with high-frequency doublets or triplets (Meehan et al., 2017), as has also been shown in rat, cat, and human in lumbar and thoracic motoneurons (Kudina and Alexeeva, 1992; Kirkwood and Munson, 1996; Kudina and Andreeva, 2010; Mrówczyński et al., 2010, 2015).

EMG recording from lateral gastrocnemius motor units during quiet stance in adult awake mice, however, are also not consistent with what would be expected if motor units were to obtain nearly maximal force during the SPR (Ritter et al., 2014). During quiet standing, motor units showed a range of rate modulation $(10-60 \mathrm{~Hz})$ that would extend outside of the SPR for slow motor units. The low firing rates observed in the mice were also not associated with the higher variance that is indicative of SPR compared with higher firing frequencies. Mean instantaneous firing frequencies have also been measured using extracellular recordings from presumed gastrocnemius and tibialis anterior motoneurons in adult mice during walking on a wheel (Hadzipasic et al., 2016). The mean firing frequency was $142 \mathrm{~Hz}$ and the median was $122 \mathrm{~Hz}$. This fits very well with our observation of a fully fused tetanus for gastrocnemius muscle at $120 \mathrm{~Hz}$. Given that the mean transition from primary range to secondary range in nonanesthetized mice occurs at $\sim 128 \mathrm{~Hz}$ (Meehan et al., 2011), we can therefore conclude that mice use the entire primary range for rate modulation of force.

\section{Summary}

Collectively, our results demonstrate that the SPR is not a feature unique to rodents, but also exists in cats and is enhanced by anesthesia. Our results concerning the physiological relevance of the SPR support the classical opinion on the frequency-force relation; that is, that firing frequencies in the higher end of the primary range are necessary to obtain a full summation for both cats and mice.

\section{References}

Bakels R, Kernell D (1993) Matching between motoneuron and muscle unit properties in rat medial gastrocnemius. J Physiol 463:307-324. CrossRef Medline

Bennett DJ, Hultborn H, Fedirchuk B, Gorassini M (1998) Synaptic activation of plateaus in hindlimb motoneurons of decerebrate cats. J Neurophysiol 80:2023-2037. CrossRef Medline

Brenner B, Eisenberg E (1986) Rate of force generation in muscle: correlation with actomyosin ATPase activity in solution. Proc Natl Acad Sci U S A 83:3542-3546. CrossRef Medline

Brownstone RM, Krawitz S, Jordan LM (2011) Reversal of the late phase of spike frequency adaptation in cat spinal motoneurons during fictive locomotion. J Neurophysiol 105:1045-1050. CrossRef Medline

Bui TV, Ter-Mikaelian M, Bedrossian D, Rose PK (2006) Computational estimation of the distribution of L-type $\mathrm{Ca}(2+)$ channels in motoneurons based on variable threshold of activation of persistent inward currents. J Neurophysiol 95:225-241. CrossRef Medline

Button DC, Gardiner K, Marqueste T, Gardiner PF (2006) Frequencycurrent relationships of rat hindlimb alpha-motoneurons. J Physiol 573: 663-677. CrossRef Medline

Chin ER, Chen D, Bobyk KD, Mázala DA (2014) Perturbations in intracellular $\mathrm{Ca} 2+$ handling in skeletal muscle in the G93A*SOD1 mouse model of amyotrophic lateral sclerosis. Am J Physiol Cell Physiol 307:C1031C1038. CrossRef Medline

Crone C, Hultborn H, Kiehn O, Mazieres L, Wigström H (1988) Maintained changes in motoneuronal excitability by short-lasting synaptic inputs in the decerebrate cat. J Physiol 405:321-343. CrossRef Medline 
Cullheim S, Fleshman JW, Glenn LL, Burke RE (1987) Membrane area and dendritic structure in type-identified triceps surae alpha motoneurons. J Comp Neurol 255:68-81. CrossRef Medline

Dibaj P, Schomburg ED, Steffens H (2015) Contractile characteristics of gastrocnemius-soleus muscle in the SOD1G93A ALS mouse model. Neurol Res 37:693-702. CrossRef Medline

Faulkner JA, Zerba E, Brooks SV (1990) Muscle temperature of mammals: cooling impairs most functional properties. Am J Physiol 259:R259R265. CrossRef Medline

Fyffe RE (1991) Spatial distribution of recurrent inhibitory synapses on spinal motoneurons in the cat. J Neurophysiol 65:1134-1149. CrossRef Medline

Gardiner PF, Kernell D (1990) The "fastness" of rat motoneurons: timecourse of afterhyperpolarization in relation to axonal conduction velocity and muscle unit contractile speed. Pflugers Arch 415:762-766. CrossRef Medline

Gordon T, Stein RB (1985) Temperature effects on the kinetics of force generation in normal and dystrophic mouse muscles. Exp Neurol 89: 348-360. CrossRef Medline

Grande G, Armstrong S, Neuber-Hess M, Rose PK (2005) Distribution of contacts from vestibulospinal axons on the dendrites of splenius motoneurons. J Comp Neurol 491:339-351. CrossRef Medline

Granit R, Kernell D, Shortess GK (1963) Quantitative aspects of repetitive firing of mammalian motoneurons, caused by injected currents. J Physiol 168:911-931. CrossRef Medline

Granit R, Kernell D, Lamarre Y (1966a) Algebraical summation in synaptic activation of motoneurons firing within the 'primary range' to injected currents. J Physiol 187:379-399. CrossRef Medline

Granit R, Kernell D, Lamarre Y (1966b) Synaptic stimulation superimposed on motoneurons firing in the 'secondary range' to injected current. J Physiol 187:401-415. CrossRef Medline

Guertin PA, Hounsgaard J (1999) Non-volatile general anesthetics reduce spinal activity by suppressing plateau potentials. Neuroscience $88: 353-$ 358. CrossRef Medline

Hadzipasic M, Ni W, Nagy M, Steenrod N, McGinley MJ, Kaushal A, Thomas E, McCormick DA, Horwich AL (2016) Reduced high-frequency motor neuron firing, EMG fractionation, and gait variability in awake walking ALS mice. Proc Natl Acad Sci U S A 113:E7600-E7609. CrossRef Medline

Henneman E (1957) Relation between size of neurons and their susceptibility to discharge. Science 126:1345-1347. CrossRef Medline

Hounsgaard J, Kiehn O (1989) Serotonin-induced bistability of turtle motoneurons caused by a nifedipine-sensitive calcium plateau potential. J Physiol 414:265-282. CrossRef Medline

Hultborn H, Denton ME, Wienecke J, Nielsen JB (2003) Variable amplification of synaptic input to cat spinal motoneurons by dendritic persistent inward current. J Physiol 552:945-952. CrossRef Medline

Iglesias C, Meunier C, Manuel M, Timofeeva Y, Delestrée N, Zytnicki D (2011) Mixed mode oscillations in mouse spinal motoneurons arise from a low excitability state. J Neurosci 31:5829-5840. CrossRef Medline

Kernell D (1965) Limits of firing frequency in cat lumbosacral motoneurons possessing different time course of afterhyperpolarization. Acta Physiol Scand 65:87-100. CrossRef

Kirkwood PA, Munson JB (1996) The incidence of initial doublets in the discharges of motoneurons of two different inspiratory muscles in the cat. J Physiol 493:577-587. CrossRef Medline

Kössler F, Küchler G (1987) Contractile properties of fast and slow twitch muscles of the rat at temperatures between 6 and 42 degrees C. Biomed Biochim Acta 46:815-822. Medline

Kössler F, Lange F, Küchler G (1987) Isometric twitch and tetanic contraction of frog skeletal muscles at temperatures between 0 to 30 degrees $\mathrm{C}$. Biomed Biochim Acta 46:809-813. Medline

Krawitz S, Fedirchuk B, Dai Y, Jordan LM, McCrea DA (2001) Statedependent hyperpolarization of voltage threshold enhances motoneuron excitability during fictive locomotion in the cat. J Physiol 532:271-281. CrossRef Medline

Kudina LP, Alexeeva NL (1992) Repetitive doublets of human motoneurons: analysis of interspike intervals and recruitment pattern. Electroencephalogr Clin Neurophysiol 85:243-247. CrossRef Medline

Kudina LP, Andreeva RE (2010) Repetitive doublet firing of motor units: evidence for plateau potentials in human motoneurons? Exp Brain Res 204:79-90. CrossRef Medline

Lännergren J, Westerblad H (1987) The temperature dependence of isomet- ric contractions of single, intact fibres dissected from a mouse foot muscle. J Physiol 390:285-293. CrossRef Medline

Lee RH, Heckman CJ (1998) Bistability in spinal motoneurons in vivo: systematic variations in rhythmic firing patterns. J Neurophysiol 80:572582. CrossRef Medline

Maglemose R, Hedegaard A, Lehnhoff J, Dimintiyanova KP, Moldovan M, Grøndahl L, Meehan CF (2017) Potassium channel abnormalities are consistent with early axon degeneration of motor axons in the G127X SOD1 mouse model of amyotrophic lateral sclerosis. Exp Neurol 292: 154-167. CrossRef Medline

Manuel M, Heckman CJ (2011) Adult mouse motor units develop almost all of their force in the subprimary range: a new all-or-none strategy for force recruitment? J Neurosci 31:15188-15194. CrossRef Medline

Manuel M, Heckman CJ (2012) Simultaneous intracellular recording of a lumbar motoneuron and the force produced by its motor unit in the adult mouse in vivo. J Vis Exp 70:e4312. CrossRef Medline

Manuel M, Iglesias C, Donnet M, Leroy F, Heckman CJ, Zytnicki D (2009) Fast kinetics, high-frequency oscillations, and subprimary firing range in adult mouse spinal motoneurons. J Neurosci 29:11246-11256. CrossRef Medline

Maratta R, Fenrich KK, Zhao E, Neuber-Hess MS, Rose PK (2015) Distribution and density of contacts from noradrenergic and serotonergic boutons on the dendrites of neck flexor motoneurons in the adult cat. J Comp Neurol 523:1701-1716. CrossRef Medline

Meehan CF, Sukiasyan N, Zhang M, Nielsen JB, Hultborn H (2010) Intrinsic properties of mouse lumbar motoneurons revealed by intracellular recording in vivo. J Neurophysiol 103:2599-2610. CrossRef Medline

Meehan CF, Grøndahl L, Nielsen JB, Hultborn H (2011) Effects of anesthesia on the intrinsic properties of adult mice in vivo. In: 2011 Neuroscience Meeting Planner. Program No. 708.07. Washington, DC: Society for Neuroscience.

Meehan CF, Mayr KA, Manuel M, Nakanishi ST, Whelan PJ (2017) Decerebrate mouse model for studies of the spinal cord circuits. Nat Protoc 12:732-747. CrossRef Medline

Montague SJ, Fenrich KK, Mayer-Macaulay C, Maratta R, Neuber-Hess MS, Rose PK (2013) Nonuniform distribution of contacts from noradrenergic and serotonergic boutons on the dendrites of cat splenius motoneurons. J Comp Neurol 521:638-656. CrossRef Medline

Mrówczyński W, Krutki P, Chakarov V, Celichowski J (2010) Doublet of action potentials evoked by intracellular injection of rectangular depolarization current into rat motoneurons. Exp Brain Res 205:95-102. CrossRef Medline

Mrówczyński W, Celichowski J, Raikova R, Krutki P (2015) Physiological consequences of doublet discharges on motoneuronal firing and motor unit force. Front Cell Neurosci 9:81. CrossRef Medline

Ranatunga KW (1980) Influence of temperature on isometric tension development in mouse fast- and slow-twitch skeletal muscles. Exp Neurol 70:211-218. CrossRef Medline

Ritter LK, Tresch MC, Heckman CJ, Manuel M, Tysseling VM (2014) Characterization of motor units in behaving adult mice shows a wide primary range. J Neurophysiol 112:543-551. CrossRef Medline

Rose PK (1981) Distribution of dendrites from biventer cervicis and complexus motoneurons stained intracellularly with horseradish peroxidase in the adult cat. J Comp Neurol 197:395-409. CrossRef Medline

Rotterman TM, Nardelli P, Cope TC, Alvarez FJ (2014) Normal distribution of VGLUT1 synapses on spinal motoneuron dendrites and their reorganization after nerve injury. J Neurosci 34:3475-3492. CrossRef Medline

Schwindt PC, Crill WE (1982) Factors influencing motoneuron rhythmic firing: results from a voltage-clamp study. J Neurophysiol 48:875-890. CrossRef Medline

Turkin VV, O’Neill D, Jung R, Iarkov A, Hamm TM (2010) Characteristics and organization of discharge properties in rat hindlimb motoneurons. J Neurophysiol 104:1549-1565. CrossRef Medline

Wienecke J, Zhang M, Hultborn H (2009) A prolongation of the postspike afterhyperpolarization following spike trains can partly explain the lower firing rates at derecruitment than those at recruitment. J Neurophysiol 102:3698-3710. CrossRef Medline

Zengel JE, Reid SA, Sypert GW, Munson JB (1985) Membrane electrical properties and prediction of motor-unit type of medial gastrocnemius motoneurons in the cat. J Neurophysiol 53:1323-1344. CrossRef Medline 